\title{
IJES
}

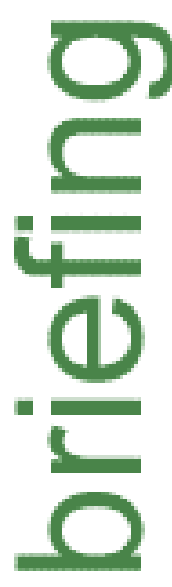

\section{RetiREMENT, PENSIONS AND The ADEQUACY OF SAVING: A Guide To The DeBATE}

\author{
James Banks \\ Richard Blundell \\ Richard Disney \\ Carl Emmerson
}




\title{
Retirement, Pensions and the Adequacy of Saving: A Guide to the Debate
}

\author{
James Banks, Richard Blundell, Richard Disney and Carl Emmerson"
}

\author{
Institute for Fiscal Studies
}

October 2002

\section{Summary}

This Briefing Note assembles the existing microeconomic evidence and sets out economic arguments relating to the current debate on the ageing population, the timing of retirement and the adequacy of financial provision for retirement in the UK. Amongst other things, the note presents empirical evidence that shows the following:

\section{Section 2 - Life expectancy and demographics}

- Life expectancy has been increasing throughout the century (Figure 2.1) and life expectancy at age 65 has risen by over three years in the last 36 years (Figure 2.2).

- Not all of this increase in life expectancy represents an increase in the number of expected years of healthy life. Indeed, the number of 'disability-free' years lived after age 65, expressed as a fraction of average years lived after age 65, has remained constant for men and has actually fallen for women (Figure 2.3).

- The proportion of the population aged 60 or over is set to increase from around $20 \%$ to around $30 \%$ over the next 30 years (Figure 2.4 ).

\footnotetext{
${ }^{*}$ Funding for this research has been provided by the ESRC Centre for the Microeconomic Analysis of Public Policy and the Leverhulme Trust, through the research programme into The Changing Distribution of Consumption, Economic Resources and the Welfare of Households. Material from the Family Expenditure Survey (FES) made available by the Office for National Statistics (ONS) through the ESRC Data Archive has been used by permission of the Controller of HMSO. The authors are also grateful to the ESRC Data Archive for providing the British Household Panel Survey (BHPS) data and to the Department for Work and Pensions (DWP) and the ONS for providing the Family Resources Survey (FRS) data used in this study. Neither the DWP, the ONS nor the ESRC Data Archive bears any responsibility for the analysis or interpretation of the data reported here. The authors would like to thank Matthew Wakefield for useful comments. The usual disclaimer applies.
} 
- The proportion of men aged 55 or over who are working has fallen markedly over the last 30 years - around one-third of 55- to 59-year-olds and over half of 60- to 64-year-olds do not work (Figure 3.1).

- The availability of early retirement windows in defined benefit pension schemes is an important determinant of the employment status of older workers (Figure 3.3).

- There are multiple 'routes' into retirement. A large fraction of older men who are not working report being long-term sick or disabled as opposed to retired or unemployed (Figure 3.4).

Section 4 - The role of the benefit system in the UK

- Around $6 \%$ of national income is spent on benefits for those over state pension age, which represents $57 \%$ of total benefit expenditures (Table 4.1 ).

- Over half of families with a member aged 60 or over are now entitled to some form of means-tested benefits (Table 4.2).

- The number of 50- to 64-year-old men claiming invalidity or incapacity benefits has almost doubled since 1980 and the number of women aged 5059 claiming these benefits has risen by a factor of over four (Figure 4.1).

- It seems unlikely, therefore, that disability itself is the sole cause of this increase in benefit dependency amongst older individuals, suggesting that trends in the 'economic dependency ratio' (the ratio of economically inactive to active adults) may be addressed by policies targeting the employment status of older workers.

Section 5 - Pension arrangements of the working-age population in the UK

- Among those working full-time, two-thirds have some form of private pension. Amongst older and richer groups of individuals, coverage is considerably higher (Figure 5.2).

- Many of those who do not have a private pension in 2000 have had one at some point in the previous eight years, and those without private pensions are more likely to have had work histories characterised by periods out of the paid labour market (Table 5.2).

- Many low earners without private pensions have a partner with a private pension, since this group is disproportionately made up of women working part-time (Table 5.2). 
Section 6-Saving

- The distribution of financial savings is very unequal, with many families and households having no, or very few, financial assets. But much of this inequality is driven by age and is to be expected within a model where people accumulate wealth over their life cycle (Figure 6.1).

- Of those aged 25 or over with no housing or pension wealth and zero or low liquid financial assets, the majority are in the poorest quarter of the income distribution and almost all are in the poorest half (Figure 6.3). This is a group likely to be eligible for means-tested benefits in their retirement.

\section{Section 7 - International issues}

- Compared to other developed countries, the UK is not unusual in terms of life expectancy, activity rates for older workers, retirement age and projected dependency ratios (Figures 7.1 and 7.3).

- The UK is not particularly comparable to the USA in terms of pension provision since the USA has so far retained the publicly provided earningsrelated pension (social security) which has been effectively privatised in the UK over the last 15 years.

- Unlike that in other EU countries, UK public pension spending is forecast to fall over the next 40 years (Figure 7.2).

\section{Section 8 - Conclusions}

- Retirement age changes are integrally linked to the adequacy of saving for retirement. By extending working lives and therefore being less long in retirement, individuals would have more time to accumulate savings (both pension and non-pension) and also need less savings.

- Low retirement income is not necessarily evidence of inadequate saving for retirement. Many older households with low incomes will have had low lifetime income, and it is not necessarily the case that such households should have saved more, given their consumption needs and the policy environment through which they have lived.

- Many unanswered research questions are key to outcomes in the future. These include: Can and will the labour market absorb more older workers? What are the consumption needs of older households? To what extent will individual behaviours (at either the saving or the retirement margin) adjust to meet the pressures of retirement income provision in an ageing population? 


\section{Introduction}

The topics of retirement, saving and pensions continue to be the focus of interest among both policy-makers and the media. This interest is stimulated by press stories concerning the adequacy of personal saving, the state of pension funds, the looming 'demographic crisis' and so on. The interest of policy-makers is reflected in the plethora of reports from 'think tanks', reviews sponsored by participants in the pension industry and publications from government sources. These have recently included the Sandler and Pickering Reviews. ${ }^{1}$ A Green Paper on pensions has been promised by the government for Autumn 2002. Despite frequent and often fundamental reforms to the UK's pension programmes in recent years, a consensus on the best shape of the programme remains as far away as ever.

This guide provides some facts and figures, accompanied by basic analysis, that are designed to help in understanding issues such as the adequacy of pension provision, the timing of early retirement, the complexity of individual savings products, the adequacy of saving, and the design and targeting of state retirement and disability benefits, which have all been identified in recent weeks and months as issues of pressing policy concern.

Attention has tended to focus on one issue at a time - the state of the pension programme, the adequacy of saving and whether, with ageing of the population, individuals will have to retire later. But these issues have to be studied together, as the issues of pension benefits, saving decisions and social security provision for older individuals cannot be studied without taking into account labour market opportunities for older workers. In particular, it is important to know whether individuals have a degree of choice over the decision of when to retire from paid work, or alternatively are constrained in their ability to work past certain ages by labour market institutions, retirement provisions, ill health or a simple lack of job opportunities.

Where people have a choice of retirement date, there is a two-way relationship between retirement and wealth. Those with greater wealth are able to retire earlier and maintain pre-retirement standards of living. But such people are also more likely to be able to choose to work longer, so being able to accrue more financial assets ready for when they do retire. This reflects a trade-off between retirement wealth already accrued and the incentives to continue to work.

There is also a sizeable group of individuals in the UK who have been forced to retire early, either through ill health or because of adverse labour market

\footnotetext{
${ }^{1}$ HM Treasury, Medium and Long-Term Retail Savings in the UK: A Review, London, 2002 (www.hm-treasury.gov.uk/Documents/Financial_Services/Savings/fin sav sand.cfm?); A.

Pickering, A Simpler Way to Better Pensions: An Independent Report by Alan Pickering, Department for Work and Pensions, London, 2002 (www.dwp.gov.uk/publications/dwp/2002/pickering/report.pdf).
} 
opportunities, who have low pension assets and few other financial resources. Understanding retirement choices, and who is constrained in their ability to take advantage of them, is a central question for government policy.

As the financial pages of newspapers frequently point out, saving, and retirement planning more generally, is an intrinsically forward-looking activity. An understanding of the policy issues needs to reflect this - individual saving behaviour will depend, at least to some extent, on current circumstances (in terms of income and consumption needs) and also on expectations of future earnings, benefit entitlements and pension incomes in relation to future consumption needs. A forward-looking calculation of this kind is particularly complex for individual households to undertake, and this means that differences in retirement and retirement saving behaviour across the population have to be analysed with more caution than, say, differences in income. Differences between individuals of different ages are particularly hard to interpret.

Moreover, it is not necessarily the case that outcomes for future generations of pensioners can be forecast by looking solely at the situation of current generations of pensioners. Prevailing economic conditions during working lives shift from generation to generation. It is therefore important to separate two types of policy issue relating to ageing - short-term policies that address outcomes for current generations of older households, and longer-term policies targeted at the causes of adverse outcomes at older ages to help current generations of younger households. In the latter case, given the forward-looking nature of retirement planning and saving decisions, stability of the policy environment across the life cycle is clearly a key element in ensuring that such plans can be easily formed.

The structure of this Briefing Note is as follows. Section 2 looks at differences in life expectancy both over time and across countries and goes on to describe the extent to which the UK population is still 'ageing'. In Section 3, we show how economic activity among older individuals has changed over time and present some evidence on how incentives to work vary by education level and pension status. Section 4 provides details of the benefit system and, in particular, the large number of older individuals who are entitled to some form of means-tested or disability-related benefit. Section 5 describes the UK pension system and how private pension coverage varies by earnings. This section then goes on to present new evidence examining how individuals who have made different pension choices in 2000 vary in terms of their characteristics over the period 1992-2000. In Section 6, we look at individuals' saving decisions. In particular, we present new evidence looking at the pattern of liquid savings, housing and private pension ownership by age and income. Section 7 describes how the issues faced by the UK differ from those faced by most other countries, both in the EU and elsewhere. Section 8 concludes. 


\section{Life expectancy and demographics}

Life expectancy has increased and is continuing to rise rapidly in the UK, as in most developed countries. Figure 2.1 plots life expectancy at birth for men and women since 1840 . Life expectancy has risen by over $50 \%$ (55\% for men and $53 \%$ for women) since 1900, and now stands at 75 and 80 years respectively.

Figure 2.1. Life expectancy at birth in the UK, by gender

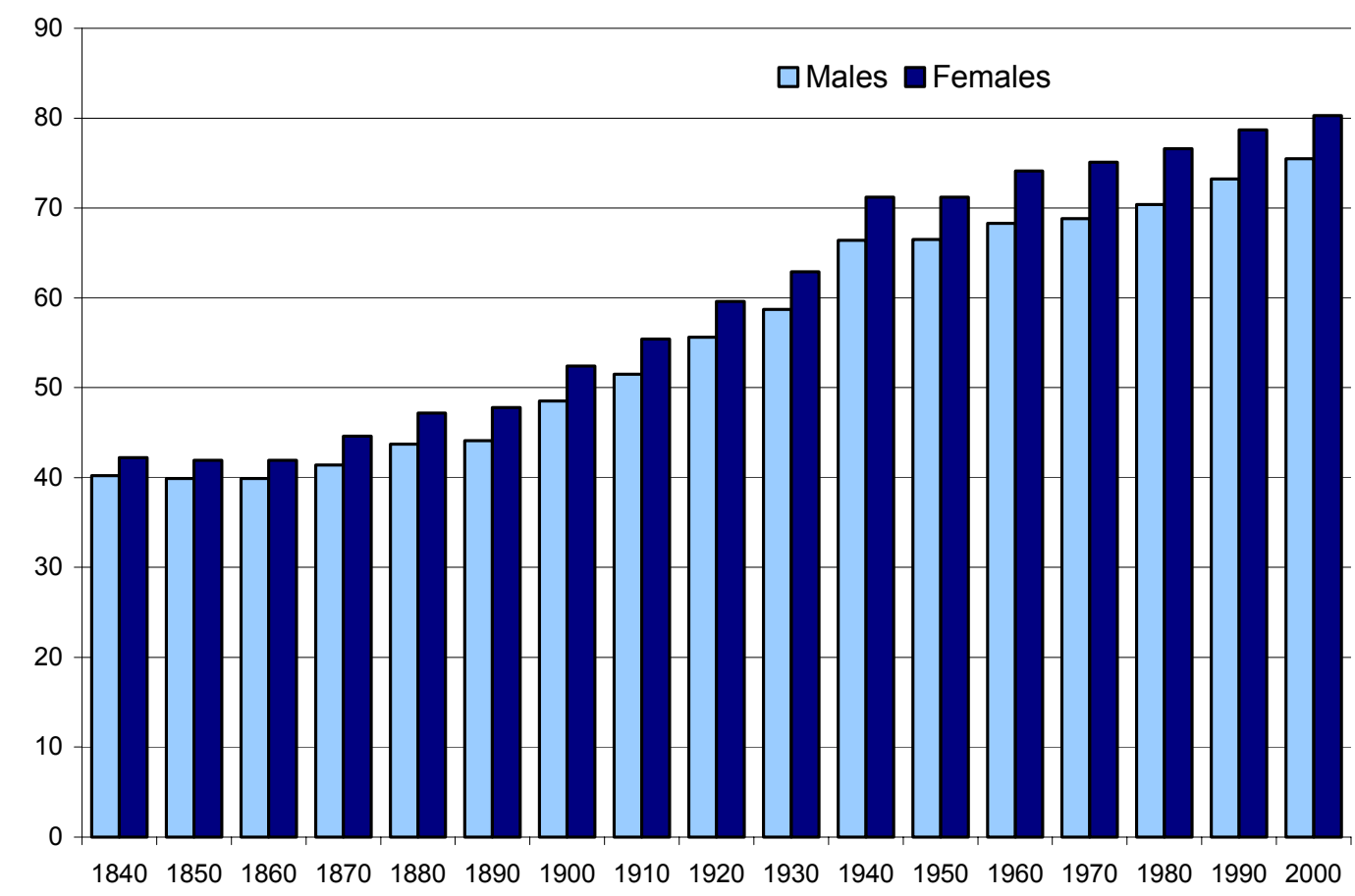

Source: Government Actuary’s Department.

Past trends in life expectancy have been driven largely by infant mortality and by improvements in medical care. Rather than life expectancy at birth, however, a more useful statistic, as far as retirement planning is concerned, is how long an individual can expect to live once they have retired. Figure 2.2 shows that the additional life expectancy in the UK for those aged 65 is now 15 years for men and nearly 20 years for women. The graph also shows that it increased by more than three years between 1961 and 1997. Within historical context, this rate of change is unprecedented for men - male life expectancy at age 65 rose by only one year between 1840 and 1960 - whilst female life expectancy at age 65 has been rising steadily since 1900 (Government Actuary's Department). The recent rise in life expectancy and the differential between men and women characterise life expectancy across all industrialised countries - Figure 2.2 also shows the remarkably large increase for women in France and Japan; these changes are similar, if somewhat muted, for men. 
Figure 2.2. International trends in life expectancy at age 65

Men

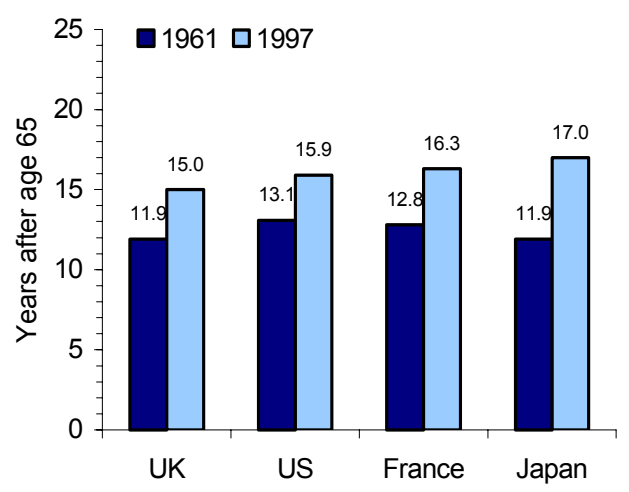

Women

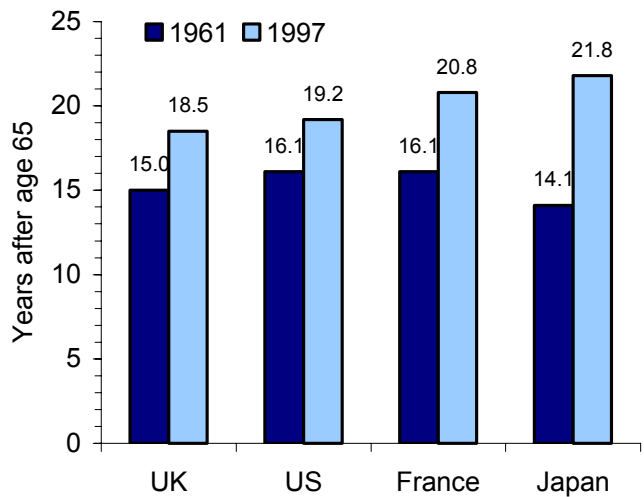

Source: OECD Health Data 2001, CD-ROM.

Added to these changes in life expectancy, however, there have been changes in the amount of later life spent with disabilities, which might be considered an essential factor in thinking about the economic implications of an ageing population. The debate over any future 'compression of morbidity' is a hot one, but what evidence there is for the UK from recent years is summarised in Figure 2.3, which shows that disability-free life expectancy has risen by just 1.2 years for men and 0.6 years for women compared with overall life expectancy increases of 2.5 and 2.0 years respectively. As a result, the fraction of life post-65 that can be expected to be disability-free has actually remained constant for men and fallen slightly for women.

Figure 2.3. Trends in healthy (disability-free) and total life expectancy at age 65 in the UK

Men

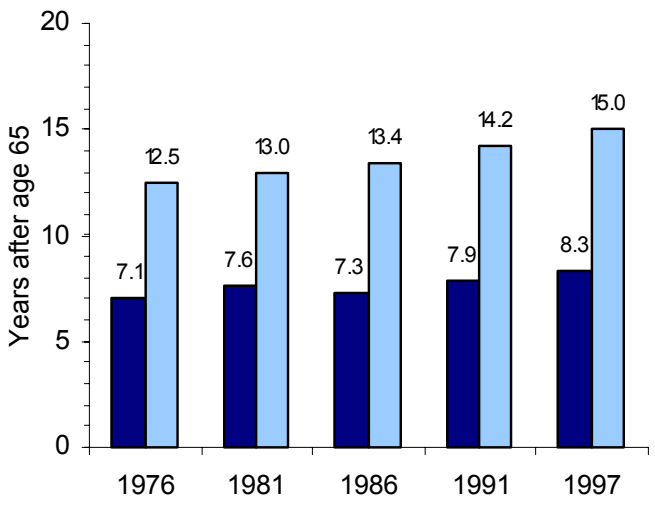

Women

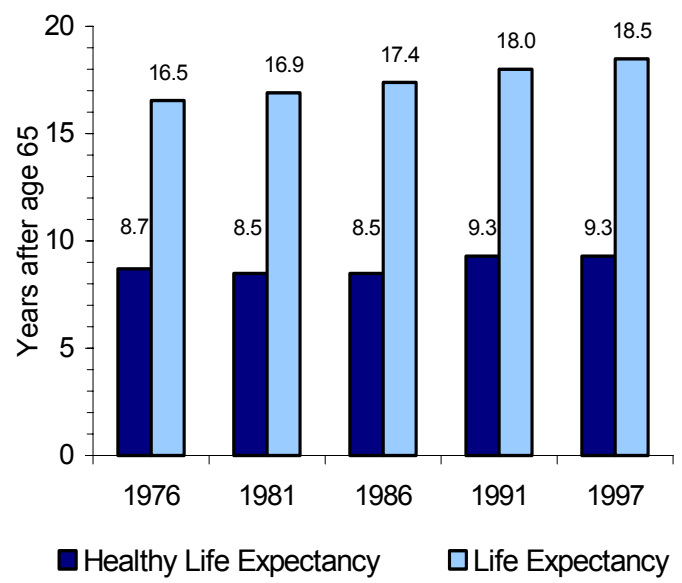

Source: OECD Health Data 2001, CD-ROM. 
Figure 2.4. UK population and projections, by age group

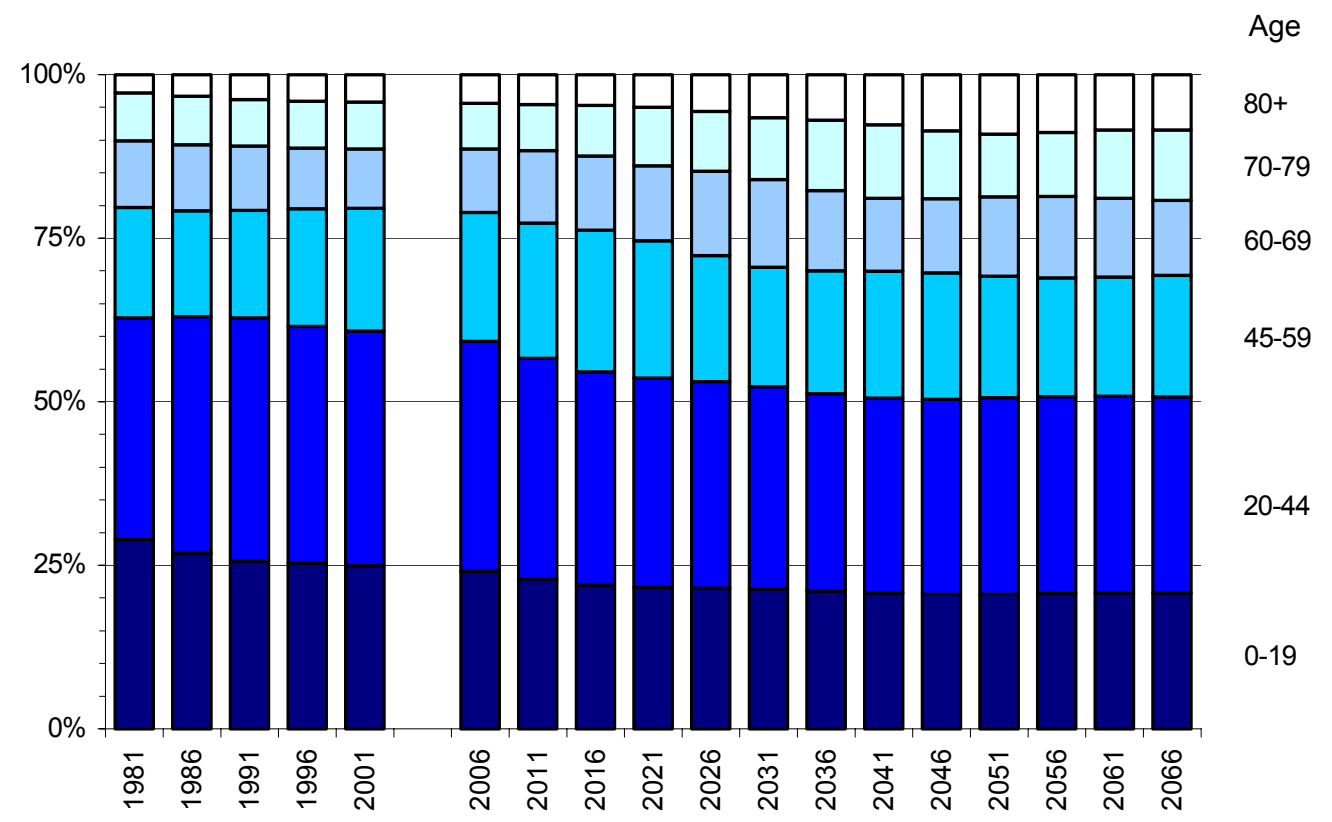

Source: Government Actuary’s Department.

Figure 2.5. Percentage of pensioners living with other adults

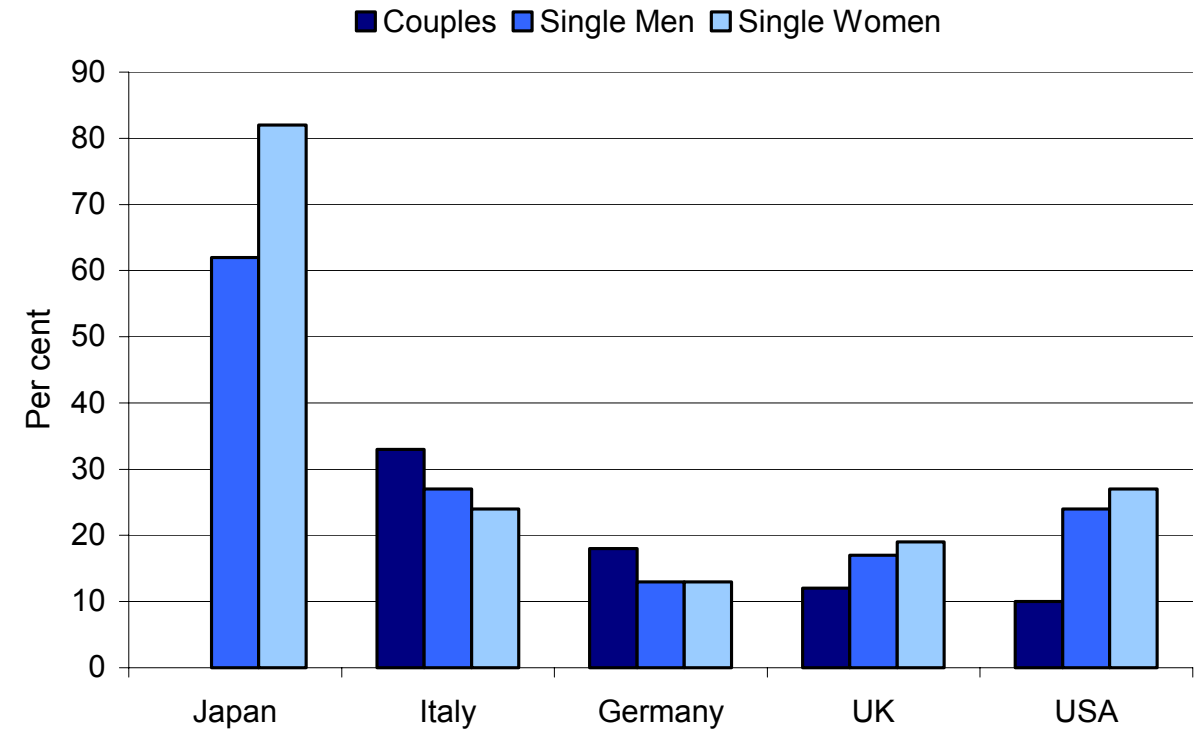

Note: Figures for couples in Japan are not available; figures relate to all men and to all women, as opposed to single men and single women, respectively.

Source: R. Disney and P. Johnson (eds), Pension Systems and Retirement Incomes across OECD Countries, Edward Elgar, Cheltenham, 2001. 
Partly as a consequence of this increase in life expectancy, the population as a whole is ageing. Figure 2.4 shows that the relative proportion of older adults is increasing. The UK population aged 60 or over is set to rise from $20 \%$ to $30 \%$ or more by 2050 , by which time the proportion aged 75 or above will be the same as the proportion aged 65 or above in 1980.

Finally, the living circumstances of older individuals will also affect retirement needs over and above the length of the post-retirement period. In contrast to some other countries with ageing populations, many older individuals in the UK live alone. Figure 2.5 shows the percentage of individuals of pension age or over who are living with other adults (in the case of single pensioners) or someone other than their spouse (in the case of couples). The UK and the USA contrast with Italy and to an even greater extent Japan, where nearly two-thirds of all male pensioners and four-fifths of all female pensioners reside with other adults.

\section{Early retirement trends and the labour market}

Since the 1960s, older men's participation in work has fallen quite dramatically. Figure 3.1 shows that for male employees in the age group 60-64, the labour force participation rate has halved to little more than $30 \%$. This fall is partially offset by the proportion self-employed, which increased from just under 5\% in 1978 to $12 \%$ in 1999 . Nonetheless, the downward trend that occurred from the late 1970 s is striking.

Among older women, there has been much less change in labour force participation rates since 1968. The proportion of women aged 50-54 in employment increased from $53.7 \%$ in 1968 to over $60 \%$ in the late 1970 s. Since then, it has remained fairly constant. Among those aged 55-59, there was an increase in the proportion employed from $42.6 \%$ in 1968 to $56.8 \%$ in 1980 , before it fell to $46.6 \%$ in 1999 . Unlike amongst older men, there has only been a very small increase in self-employment among older women. For example, $4.0 \%$ of women aged 50-54 were self-employed in 1980 compared to $5.6 \%$ in 1999 . It is important to remember that the trends shown in Figure 3.1 are a combination of both time and cohort effects. Evidence that participation rates have not changed for women could be the result of no differences either between cohorts or over time. Alternatively, it could be that there have been important cohort and time effects but that these have cancelled out.

It is clear that for many individuals, the age at which the state pension is first received is no longer the key date when planning retirement - the majority of people are already out of the labour market before that age. It does still remain the most common age of retirement. 
Figure 3.1. UK labour force participation, employed and self-employed, by age and gender (\%)
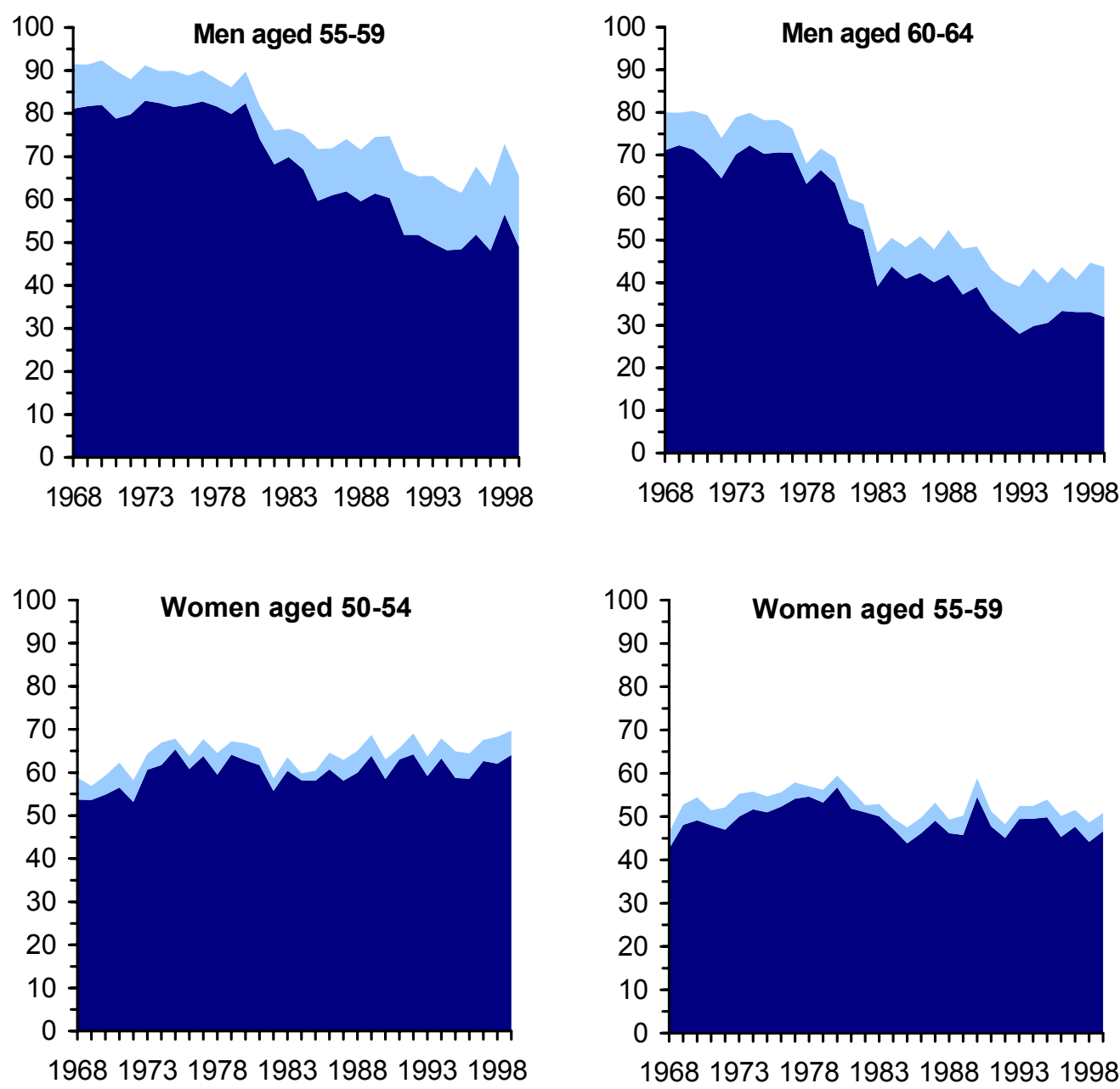

Employed Self-employed

Source: Family Expenditure Survey.

Over this period, the earnings opportunities for lower-skilled older workers fell away dramatically. This reflected two phenomena. The first was the rapidly growing differential between the earnings of those workers with educational qualifications and those without. Mean earnings are higher among those who left school after the compulsory school-leaving age than among those who left at or before this age. Figure 3.2 shows that among older male workers, the difference has been growing. Over the period from 1978 to 1996, real wages among the lower-educated group grew by $15 \%$, compared with $21 \%$ among those with more years of schooling. These figures are equivalent to annual real increases of $0.8 \%$ and $1.1 \%$ respectively. The graph also shows that older workers have experienced a slower-than-average increase in real wages over the period. 
Figure 3.2. Growth in real wages for men aged 50 or over in the UK, by education, compared with real growth in the average earnings index

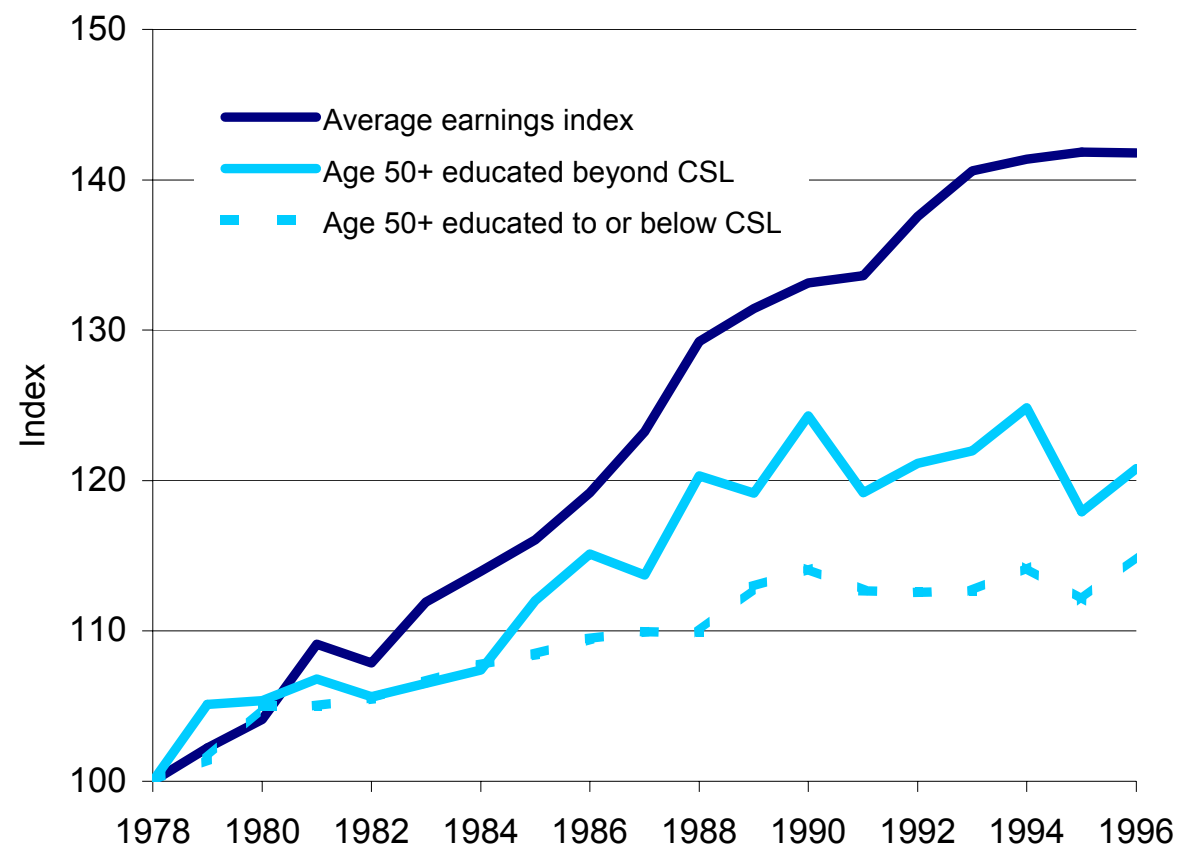

Notes: CSL refers to the compulsory school-leaving age. Wages are adjusted for non-random selection into the labour market using the methodology set out in R. Blundell, H. Reed and T. Stoker, 'Interpreting aggregate wage growth', IFS Working Paper no. 99/13, 1999 (www.ifs.org.uk/workingpapers/wp9913.pdf). Wages are assumed to be log-normally distributed and deflated to take account of price inflation using the retail price index.

Source: Family Expenditure Survey.

There are many routes to retirement, including the invalidity benefit and incapacity benefit system. The strong growth in the number of recipients of these benefits during the late 1980s and 1990s is documented in Section 4. This growth occurred for those with private pensions as well as for those in the state pension scheme. Are there signs that the different financial incentives underlying pension schemes influence retirement decisions? One way to consider this is to examine the probability that an individual has not retired by a certain age (known as a survival curve) by whether or not they are a member of a private pension. Figure 3.3 shows that those without a private pension are less likely to be in work in their early $50 \mathrm{~s}$ than those with a private pension (i.e. there is a larger exit to retirement at early ages among those without a private pension). However, by their late $50 \mathrm{~s}$, those with private pensions begin to leave the labour market at a more rapid rate than those who do not have a private pension. This, and the related analysis in Blundell, Meghir and Smith (2002), ${ }^{2}$ shows that the

${ }^{2}$ R. Blundell, C. Meghir and S. Smith, 'Pension incentives and the pattern of early retirement', Economic Journal, 2002, vol. 112, pp. C153-70. 
availability of early retirement windows in defined benefit pension schemes is an important determinant of retirement among scheme members.

Figure 3.3. Survival probabilities for men in the UK, by pension status

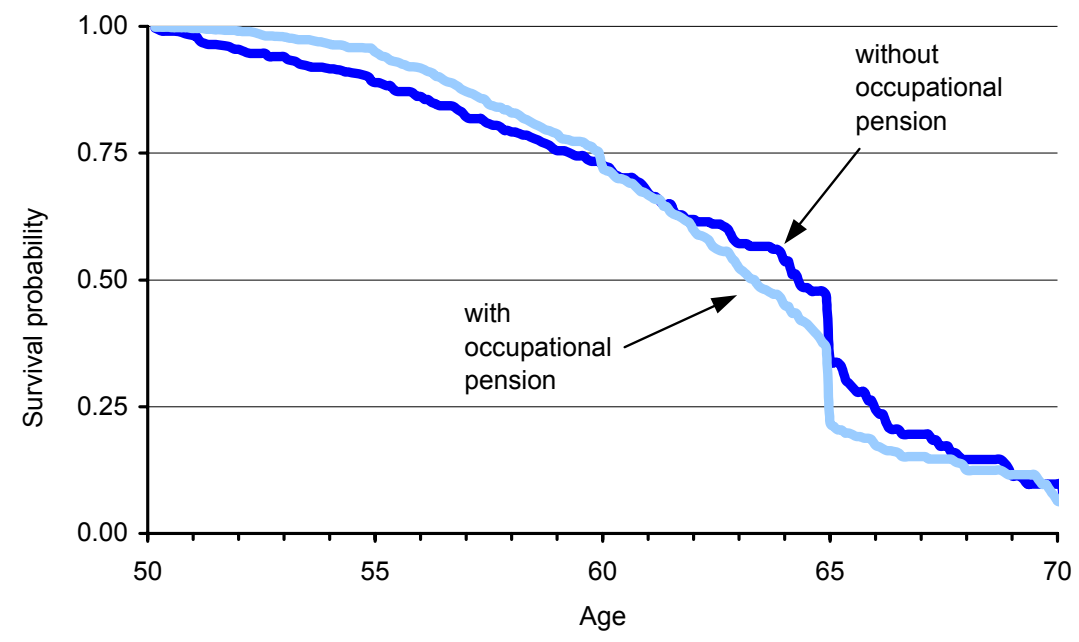

Source: R. Blundell, C. Meghir and S. Smith, 'Pension incentives and the pattern of early retirement', Economic Journal, 2002, vol. 112, pp. C153-70, using data from the British Retirement Survey.

Figure 3.4. Patterns of activity and inactivity among 50- to 69-year-old men in the UK, 2000-01

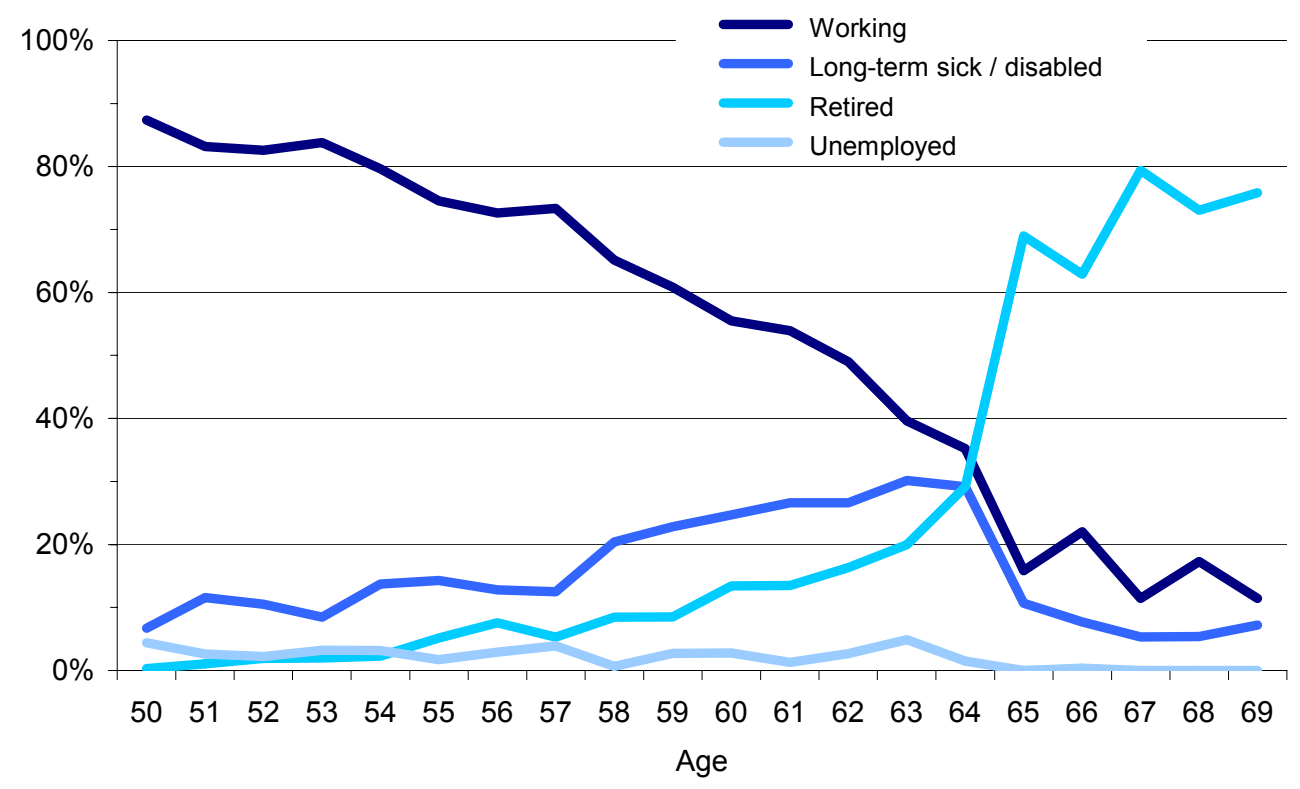

Source: Family Resources Survey, 2000-01. 
The pattern of 'early retirement' is common to many countries, although the routes taken vary widely. ${ }^{3}$ Figure 3.4 plots the economic activity of men aged 50-69 in the UK in 2000-01. Just over one-third (35\%) of men aged 64 are still in paid employment, just under one-third (29\%) report that they are retired, with the same percentage reporting that they are long-term sick or disabled. (The remainder state that they are unemployed.) This again shows that it is only a minority of men who are still in work by the state pension age of 65 .

\section{The role of the benefit system in the UK}

In 2001-02, spending on the basic state pension and additional earnings-related pensions (mainly SERPS) came to a total of $£ 42$ billion (4.1\% of GDP). In addition to this, there are a range of other state benefits that can be received by individuals in their retirement. These are shown in Table 4.1 alongside the amount spent on them by the state in 2001-02.

Table 4.1. State spending on those over working age, 2001-02

\begin{tabular}{l|cc}
\hline Payment & $£$ million & \% of GDP \\
\hline Retirement pension - basic & 36,470 & 3.6 \\
Retirement pension - earnings-related & 5,500 & 0.5 \\
Minimum income guarantee & 4,405 & 0.4 \\
Housing benefit & 4,365 & 0.4 \\
Attendance allowance & 3,130 & 0.3 \\
Disability living allowance & 2,100 & 0.2 \\
Winter fuel payments & 1,700 & 0.2 \\
Council tax benefit & 1,365 & 0.1 \\
TV licence for those aged 75 or over & 370 & 0.0 \\
Other & 880 & 0.1 \\
Total & 60,285 & 6.0 \\
As $a$ \% of total benefit expenditure & $57 \%$ & \\
\hline Note: Figr
\end{tabular}

Note: Figures are for estimated out-turns. The nine largest items of spending are listed separately; the remainder have been grouped in 'other'.

Source: Table 9 of Department for Work and Pensions, Social Security Departmental Report: The Government's Expenditure Plans 2002-03 to 2003-04, Cm. 5424, London, 2002 (www.dwp.gov.uk/publications/dwp/2002/dwpreport/index.htm).

In addition to these payments, the government will introduce the new pension credit in October 2003. This essentially operates as a taper on the minimum income guarantee, which is currently withdrawn at a rate of $100 \%$. The pension credit will be withdrawn at a rate of $40 \%$. However, this withdrawal rate will interact with those of other benefits. Individuals in receipt of the pension credit who are also on the housing benefit taper will face an effective tax rate of $79 \%$.

\footnotetext{
${ }^{3}$ See J. Gruber and D. Wise (eds), Social Security and Retirement around the World, University of Chicago Press, Chicago, 1999.
} 
Those who are also having council tax benefit withdrawn will face an effective tax rate of $91 \%$. The reform will, however, lead to a fall in the mean effective marginal tax rate for those aged 65 or over from $47.8 \%$ to $39.2 \%$. Furthermore, more individuals will see their effective marginal tax rate fall as a result of the reform than will see it rise. ${ }^{4}$

Withdrawing the pension credit at a slower rate than the minimum income guarantee will result in more individuals being eligible for some form of meanstested benefit. Table 4.2 shows the proportion of individuals who are estimated to be eligible for some income support, minimum income guarantee, pension credit, housing benefit or council tax benefit, both without and with the pension credit reform. On average, $40.6 \%$ of families with a member aged 50 or over are currently eligible for some means-tested benefit. This percentage is estimated to increase to $44.9 \%$ as a result of the pension credit reform. In practice, initial eligibility for these means-tested benefits is likely to be slightly overstated by the figures presented in Table 4.2, since the private incomes of younger cohorts in the future are likely to be higher in real terms. ${ }^{5}$ This effect will only be sufficiently strong to mitigate partially the increase in the proportion of those aged 60 or over who are eligible for means-tested benefits.

Table 4.2. Percentage of families entitled to means-tested benefits, without and with pension credit reform

\begin{tabular}{l|cccccc}
\hline & \multicolumn{6}{|c}{ Age } \\
& $50-59$ & $60-64$ & $65-74$ & $75+$ & All 50+ & All 60+ \\
\hline Without pension credit & & & & & & \\
Single males & 44.7 & 52.5 & 55.3 & 62.9 & 53.0 & 57.9 \\
Single females & 45.6 & 56.5 & 65.9 & 75.5 & 65.4 & 69.6 \\
Couples & 9.9 & 24.7 & 33.2 & 51.5 & 23.8 & 34.8 \\
All & 20.7 & 34.7 & 47.4 & 66.2 & 40.6 & 51.4 \\
& & & & & & \\
With pension credit & & & & & & \\
Single males & 44.7 & 55.1 & 63.8 & 72.2 & 57.8 & 65.5 \\
Single females & 46.0 & 57.9 & 73.5 & 81.8 & 70.7 & 75.9 \\
Couples & 9.9 & 27.0 & 40.9 & 61.3 & 27.4 & 41.3 \\
All & 20.7 & 36.8 & 55.2 & 74.1 & 44.9 & 58.0 \\
\hline
\end{tabular}

Note: In couples, age refers to the age of the oldest person in the couple.

Source: The IFS tax and benefit model, TAXBEN, using data from the 1998-99 Family Resources Survey.

\footnotetext{
${ }^{4}$ For more details of the pension credit, see T. Clark, Recent Pensions Policy and the Pension Credit, IFS Briefing Note no. 17, 2001 (www.ifs.org.uk/pensions/bn17.pdf) and T. Clark, Rewarding Saving and Alleviating Poverty? The Final Pension Credit Proposals, IFS Briefing Note no. 22, 2002 (www.ifs.org.uk/pensions/bn22.pdf).

${ }^{5}$ For a discussion, see M. Brewer, T. Clark and M. Wakefield, 'Five years of social security reforms in the UK', IFS Working Paper no. 02/12, 2002

(www.ifs.org.uk/workingpapers/wp0212.pdf).
} 
Eligibility for means-tested benefits is higher among older groups, for three main reasons. Firstly, older people are more likely not to be in paid employment. Second, economic growth means that earlier cohorts will be poorer on average. Third, those who have been in receipt of price-indexed pension income (such as SERPS or the majority of private pension income) for longer will have seen it fall more relative to average earnings. Eligibility for means-tested benefits is also higher among single individuals than among couples, with single women in particular having the highest levels of eligibility. For example, three-quarters of single women aged 60 or over will be entitled to one of the principal meanstested benefits after the pension credit reform.

An important consideration is that the figures in Table 4.2 refer to the percentage of individuals who are eligible for different means-tested benefits. The actual percentage of individuals claiming these benefits is lower, since many people do not claim the benefits to which they are entitled. The latest government estimates suggest that in 2000-01, among those pensioners eligible for income support between $64 \%$ and $78 \%$ actually claimed. Since those who do not claim the benefit to which they are entitled are, on average, entitled to smaller amounts, take-up by overall expenditure is estimated to have been higher, with between $74 \%$ and $86 \%$ of income support expenditure for pensioners being taken up. ${ }^{6}$

Figure 4.1. Numbers of claimants of invalidity and incapacity benefit aged 50 or over (thousands)
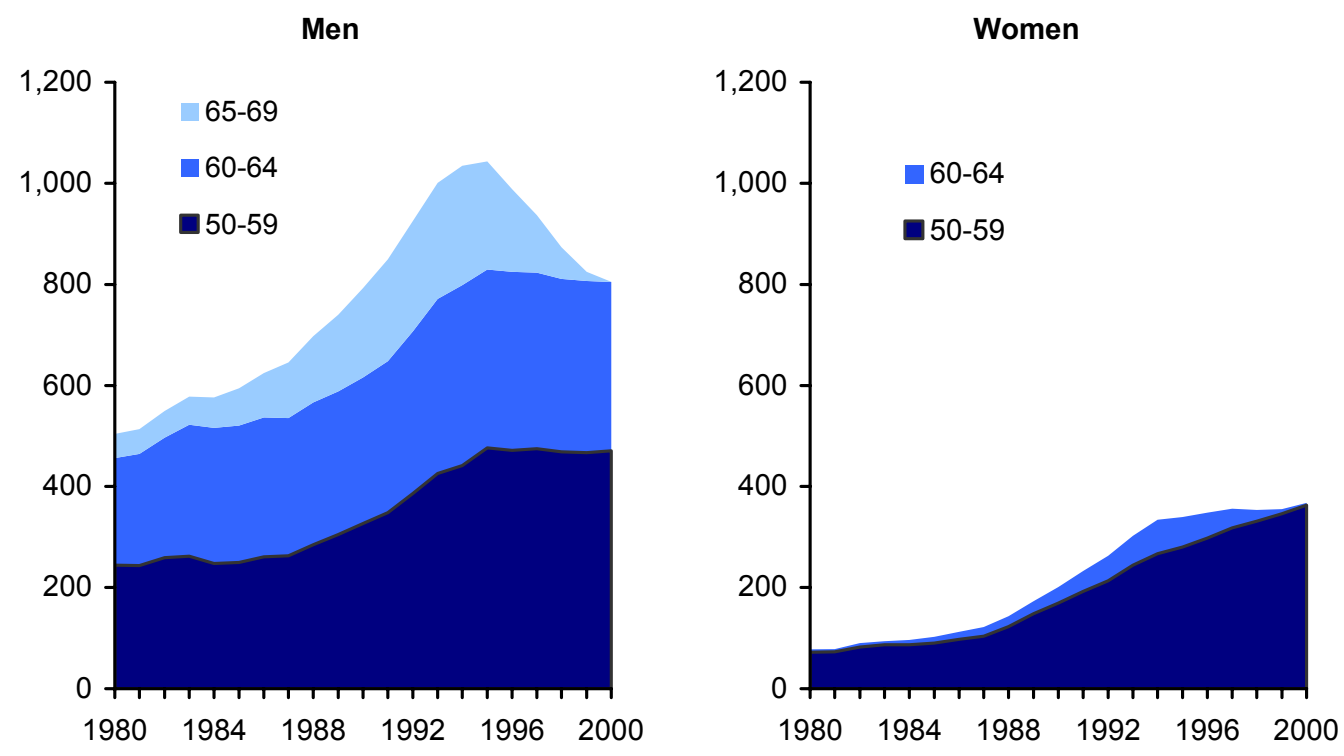

Source: Department for Work and Pensions.

\footnotetext{
${ }^{6}$ Source: Tables 1.1 and 1.2 of Department of Social Security, Income Related Benefits: Estimates of Take-Up in 1999-2000, London, 2001 (www.dss.gov.uk/asd/tu9900f.pdf).
} 
Individuals aged under the state pension age may also be able to claim incapacity benefit. This replaced invalidity benefit in $1995 .{ }^{7}$ As shown in Figure 4.1, the number of men aged 50 or over claiming invalidity benefit doubled between May 1980 and April 1995 (from 504,500 to 1,066,000). The number of women aged 50 or over claiming increased more than fourfold over the same period (from 77,700 to 362,000 ). Since 1995 , there has been a reduction in the number of claimants, due to the fact that individuals used to be able to claim the benefit for up to five years beyond the state pension age but this has now been phased out. Figure 4.1 also shows that there has not been a decline in claimant numbers among those aged below the state pension age. Further IFS research to be published in the autumn will examine these trends in more detail.

It is worth relating Figure 4.1 to the trends in disability-free life expectancy highlighted in Figure 2.3. Whilst the numbers on benefits have increased rapidly, the earlier graph shows that, if anything, older individuals now have higher disability-free life expectancies (albeit not rising so fast as their total life expectancies) than in the past. It seems unlikely, therefore, that disability itself is the sole cause of this increase in benefit dependency amongst older individuals. This in turn suggests that trends in the 'economic dependency ratio' (EDR) (the ratio of economically inactive to active individuals) may be addressed by policies targeting the employment status of older workers.

\section{Pension arrangements of the working-age population in the UK}

The UK pension system allows individuals a great deal of choice over how much they save for their retirement and in which form they save. Figure 5.1 shows the current range of options available. While individuals are not currently able to contract out of the first tier of (mandatory) pension coverage, they do have a large degree of choice at the second (also mandatory) tier of pension coverage. Employees can choose to remain in the state second pension, or they can choose to contract out of this scheme and join their employer's pension scheme (if offered) or open their own individual pension account (known as a personal pension or a stakeholder pension). In return for forgoing their future second-tier state pension, individuals (and, where relevant, their employers) pay a reduced rate of National Insurance contribution. ${ }^{8}$

\footnotetext{
${ }^{7}$ For a detailed discussion, see, for example, T. Burchardt, 'The evolution of disability benefits in the UK: re-weighting the basket', Centre for Analysis of Social Exclusion, CASEpaper no. 26, 1999 (http://sticerd.lse.ac.uk/dps/case/cp/CASEpaper26.pdf).

${ }^{8}$ For a more detailed discussion of the UK pension system and the contracting-out arrangements, see, for example, R. Disney, C. Emmerson and S. Smith, 'Pension reform and economic performance in Britain in the 1980s and 1990s', in R. Blundell, D. Card and R. B. Freeman (eds), Seeking a Premier League Economy, University of Chicago Press, Chicago, forthcoming (www.nber.org/books/bcf/pension3-2001.pdf).
} 
Figure 5.1. Schema of the UK pension system, 2002

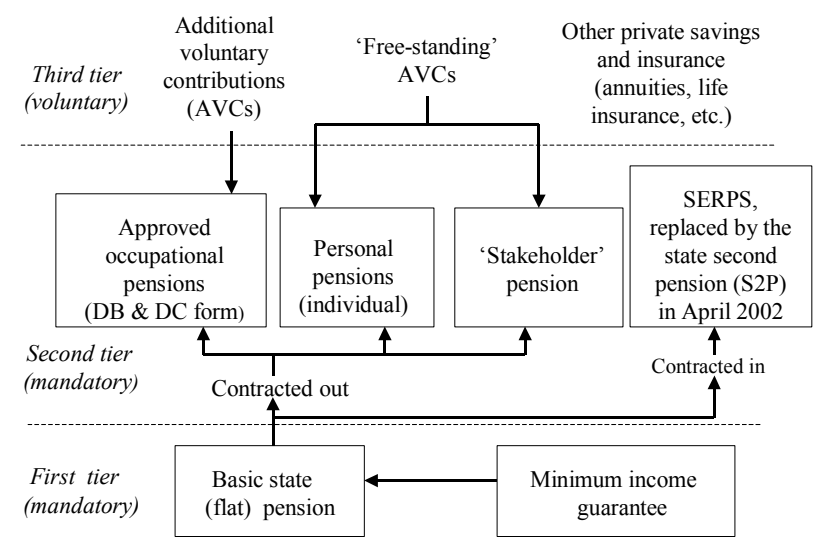

Many employees have chosen to contract out of the state scheme. Data from the 2000 General Household Survey show that among those working full-time, 67\% of men and $66 \%$ of women were members of either an occupational pension scheme or a personal pension. Not surprisingly, those aged under 25 are least likely to be a member of a pension scheme currently. Coverage of part-time women is also lower, at around $37 \%{ }^{9}$

Coverage of private pensions also varies considerably by earnings level. This is shown in Figure 5.2 using data from the tenth wave (Autumn 2000) of the British Household Panel Survey. In total, $46.5 \%$ of those in paid employment report being a member of an occupational pension scheme, with a further $7.0 \%$ reporting that they also have a personal pension in that year ${ }^{10}$ and $10.0 \%$ having only a personal pension. Those with higher earnings are much more likely to be members of an occupational pension scheme, with $79.9 \%$ of those in the highestearning $10 \%$ of the population having either an occupational scheme or an occupational scheme and a personal pension. In contrast to occupational pensions, with personal pensions there is not a monotonic increase of coverage with regards to earnings level. Those with lower levels of earnings are less likely to have any private pension arrangement. Either these people will be contracted into SERPS (and from April 2002, the state second pension), or they will have

\footnotetext{
${ }^{9}$ Figures from table 6.1 of Office for National Statistics, Living in Britain: Results from the 2000/01 General Household Survey, The Stationery Office, London, 2001 (www.statistics.gov.uk/lib/resources/fileAttachments/GHS2000.pdf).

${ }^{10}$ There are several possible explanations for individuals reporting that they have contributed to more than one type of pension. Perhaps most obviously, some will have changed pension status at some point during the last 12 months (for example, if they have moved jobs). Another explanation is that those who are members of a group personal pension might report that they are both a member of a scheme offered by their employer and a member of a personal pension.
} 
earnings below the lower earnings limit (LEL) and hence will not be accruing any second-tier state pension rights. ${ }^{11}$

Figure 5.2. Private pension coverage in the UK, by earnings decile, 2000

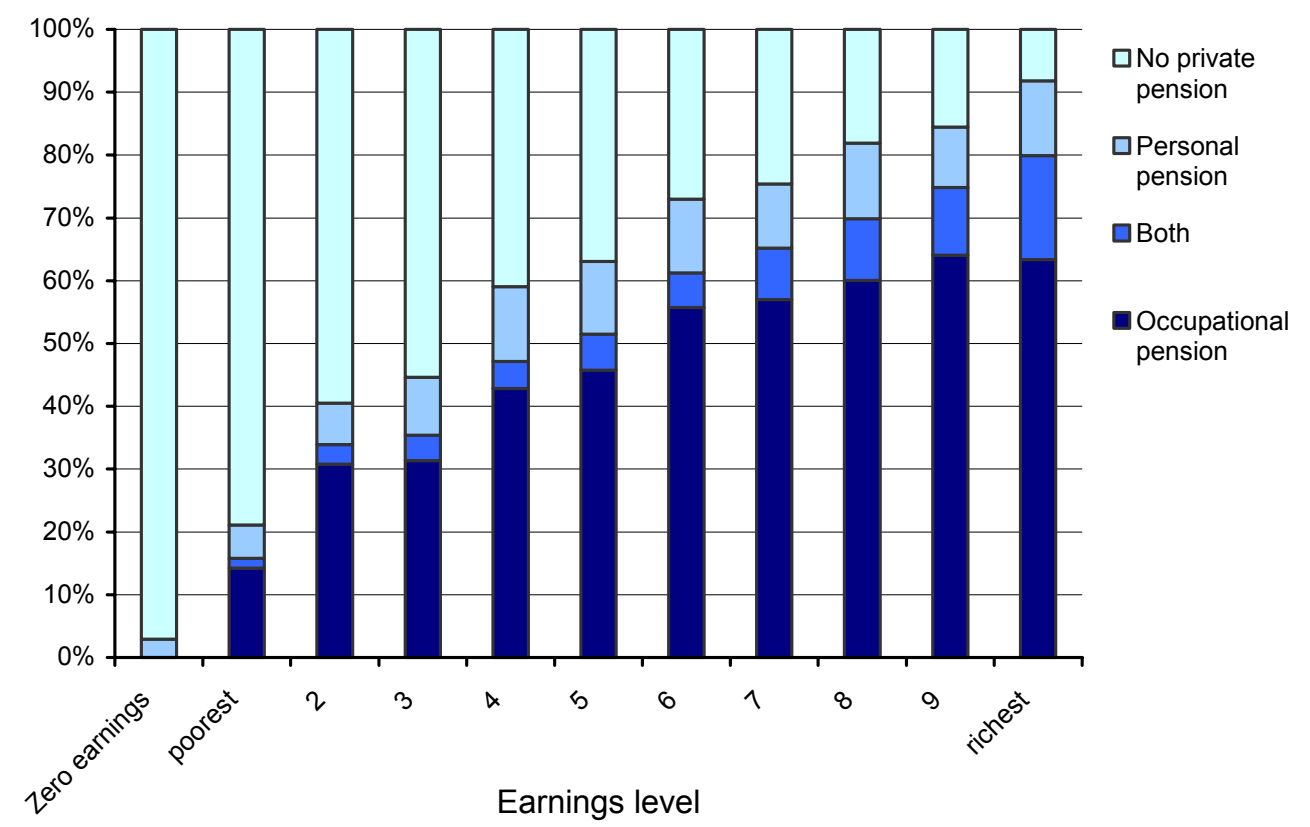

Note: Sample includes only individuals aged 20-59 who are not currently self-employed. Total sample size is 9,329 individuals. These are split between 2,373 in the zero earnings category and approximately 696 in each of the 10 earnings deciles.

Source: Authors' calculations using data from the British Household Panel Survey, 2000.

Despite the fact that an individual's employment status, earnings and pension status often change over time, the 1998 Green Paper chose to target stakeholder pensions at individuals based on their current characteristics. In particular, they have been aimed at middle earners who do not already have a private pension. ${ }^{12}$ Table 5.1 takes individuals in paid employment or self-employment in 2000 and splits them according to their current earnings - those earning less than $£ 10,000$ a year, those earning $£ 10,000$ to $£ 21,999$ a year and those earning $£ 22,000$ or more. A quarter of individuals fall into the lowest earnings band, just under half in the middle band and the remaining $30 \%$ in the highest earnings category. Of

\footnotetext{
${ }^{11}$ The state second pension also provides credits for recipients of invalid care allowance, those caring for individuals receiving attendance allowance or disability living allowance, and those receiving child benefit where their youngest child is aged under 5. For a discussion of the state second pension, see, for example, P. Agulnik, 'The proposed State Second Pension', Fiscal Studies, 1999, vol. 20, pp. 409-21, a summary of which is available at www.ifs.org.uk/publications/fiscalstudies/fsabs20agul.shtml.
}

${ }^{12}$ Department of Social Security, A New Contract for Welfare: Partnership in Pensions, Cm. 4179, London, 1998 (www.dwp.gov.uk/publications/dss/1998/pengp/index.htm). 
those who are in the middle earnings band in 2000 , only $22 \%$ do not have some kind of private pension arrangement. This compares with $57 \%$ of individuals in the lower earnings category and just $7 \%$ in the higher earnings category.

Table 5.1. Pension coverage, by gross annual earnings, 2000

\begin{tabular}{l|cccc}
\hline & $\begin{array}{c}\text { 'Low' } \\
(<£ 10,000)\end{array}$ & $\begin{array}{c}\text { 'Mid' } \\
(£ 10,000 \text { to } \\
£ 21,999)\end{array}$ & $\begin{array}{c}\text { 'High' } \\
(£ 22,000+)\end{array}$ & All \\
\hline \% in each earnings band & 24.9 & 46.7 & 28.5 & 100.0 \\
\% with occupational pension & 30.8 & 57.2 & 67.8 & 53.7 \\
\% with a personal pension & 9.2 & 13.7 & 10.5 & 11.7 \\
\% with both & 3.4 & 6.8 & 14.3 & 8.1 \\
\% with no private pension & 56.6 & 22.3 & 7.3 & 26.6 \\
& & & & \\
Sample size & 597 & 1,121 & 684 & 2,402 \\
\hline
\end{tabular}

Notes: Includes individuals in paid employment or self-employment in wave 10, aged 25-59 (inclusive), and present in waves 2 to 10 of the BHPS. An annex explaining the figures in this table in more detail is available on request to the authors.

Source: Authors' calculations using data from the British Household Panel Survey, 1992-2000.

It is important to note that both Figure 5.2 and Table 5.1 only provide a snapshot of pension coverage at a point in time. Evidence published elsewhere shows that over the seven-year period $1992-98,60 \%$ of employees accrued rights to more than one type of pension scheme - for example, some accrued rights to SERPS and to a private pension scheme. ${ }^{13}$ Table 5.2 takes the same 2,402 individuals shown in Table 5.1 and looks at how their characteristics over the period 1992 2000 vary by their earnings level and pension status in 2000. For example, rows 3 to 5 show the percentage of individuals who are in each age group by their pension status and earnings level in 2000. Of those who report not being a member of a private pension scheme in 2000 who are 'low' earners, $24.0 \%$ are aged $25-34,45.3 \%$ are aged $35-49$ and $30.8 \%$ are aged $50-59$. These figures can be compared with the 'low' earners who are members of a private pension scheme in 2000 . The table shows that $14.7 \%$ of this group are aged $25-34,52.9 \%$ are aged 35-49 and 32.4\% are aged 50-59. Hence, among 'low' earners, those individuals who are currently in a private pension scheme are, on average, older than those who are not in one. This pattern is also found among 'mid' and 'high' earners. For example, among 'mid' earners who are not in a private pension scheme in $2000,43.6 \%$ are aged $25-34$, compared with $28.2 \%$ of those 'mid' earners who are in one. Among 'high' earners who are not in a private pension scheme in $2000,40.0 \%$ are aged $25-34$, compared with $16.2 \%$ of those 'high' earners who are in one.

\footnotetext{
${ }^{13}$ See table 2 of R. Disney, C. Emmerson and M. Wakefield, 'Pension reform and saving in Britain', Oxford Review of Economic Policy, 2001, vol. 17, no. 1, pp. 70-94.
} 
Table 5.2. Individual characteristics from 1992 to 2000, by earnings level and pension choice in 2000: individuals aged 25-59 only

\begin{tabular}{|c|c|c|c|c|c|c|c|c|c|}
\hline Pension status in 2000: & Not in & private per & ion schem & $n 2000$ & In $a_{1}$ & vate penst & $n$ scheme & 2000 & \\
\hline Earnings level in 2000: & 'Low' & 'Mid' & 'High’' & All & 'Low' & 'Mid' & 'High' & All & All \\
\hline$\%$ male & 8.9 & 50.4 & 72.0 & 30.1 & 8.1 & 51.1 & 71.9 & 52.3 & 46.4 \\
\hline$\%$ aged $25-34$ & 24.0 & 43.6 & 40.0 & 32.9 & 14.7 & 28.2 & 16.2 & 21.9 & 24.9 \\
\hline$\%$ aged $35-49$ & 45.3 & 35.2 & 36.0 & 40.6 & 52.9 & 45.9 & 62.9 & 53.1 & 49.8 \\
\hline$\%$ aged $50-59$ & 30.8 & 21.2 & 24.0 & 26.5 & 32.4 & 25.8 & 20.8 & 25.0 & 25.4 \\
\hline$\%$ experiencing a period out of employment & 64.2 & 48.4 & 38.0 & 56.0 & 38.6 & 23.8 & 12.8 & 22.0 & 31.0 \\
\hline Average period in employment (years) & 6.7 & 7.5 & 8.1 & 7.1 & 8.1 & 8.5 & 8.7 & 8.5 & 8.1 \\
\hline Median earnings when employed & $£ 5,236$ & $£ 13,017$ & $£ 21,635$ & $£ 9,018$ & $£ 7,151$ & $£ 15,341$ & $£ 26,978$ & $£ 17,876$ & $£ 15,378$ \\
\hline$\%$ occasional 'low' earner & 71.6 & 54.8 & 20.0 & 61.0 & 65.6 & 31.7 & 5.2 & 27.2 & 36.1 \\
\hline$\%$ occasional 'high' earner & 4.1 & 18.4 & 78.0 & 15.5 & 3.5 & 28.6 & 50.8 & 32.9 & 28.3 \\
\hline Median financial wealth ${ }^{\mathrm{b}}$ in 1995 & $£ 300$ & $£ 300$ & $£ 1,140$ & $£ 400$ & $£ 2,000$ & $£ 1,400$ & $£ 4,010$ & $£ 2,028$ & $£ 1,500$ \\
\hline$\%$ with $<£ 1,500$ in financial wealth ${ }^{\mathrm{b}}$ in 1995 & 65.4 & 64.8 & 52.0 & 64.1 & 46.3 & 50.4 & 33.4 & 43.7 & 49.1 \\
\hline Sample size & 338 & 250 & 50 & 638 & 259 & 871 & 634 & 1,764 & 2,402 \\
\hline
\end{tabular}

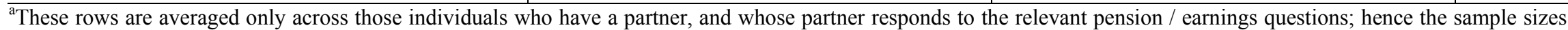
are smaller, although all exceed 150 except for 'high' earners without a private pension.

${ }^{\mathrm{b}}$ Financial wealth refers to savings and investments and excludes pension wealth and any debts.

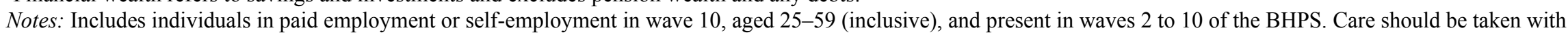

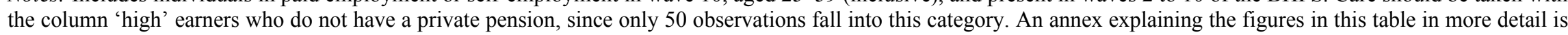
available here.

Source: Authors' calculations using data from the British Household Panel Survey, 1992-2000. 
The table also shows that a significant proportion of people are only occasional members of a private pension scheme, so that many of those who are not currently in a scheme were in one at some point in the past. Among those who are not members of a private pension scheme in 2000, 31.7\% of 'low' earners, $56.4 \%$ of 'mid' earners and $74.0 \%$ of 'high' earners report being a member of one in at least one of the previous eight years (1992-99). Among those who are members of a private pension scheme in $2000,73.7 \%$ of 'low' earners, $45.6 \%$ of 'mid' earners and $24.8 \%$ of 'high' earners report that they were not a member of one for all of the years 1992-99 (but may have been for some of these years).

Those currently not in a private pension scheme are also much more likely to have experienced periods out of the labour market than those who are currently in one. For example, $48.4 \%$ of those 'mid' earners not in a private pension scheme in 2000 experienced a period not in paid employment or selfemployment over the period 1992-99, compared with $23.8 \%$ of those 'mid' earners who are in one. Those currently not in a private pension scheme tend to earn less when they are in paid employment. Median earnings (averaged across periods when in work) among 'mid' earners not in a private pension scheme in 2000 are $£ 13,017$, compared with $£ 15,341$ among those 'mid' earners who are in one. This is not surprising since it is consistent with the idea that those who would be expected to save less for their retirement are doing precisely that.

Also shown in Table 5.2 are some details of individuals' family circumstances. Among those who are not private pension scheme members in 2000, $74.0 \%$ are currently living with a partner, compared with $80.2 \%$ of those who are private pension scheme members. Among these groups, those not currently in a private pension scheme are less likely than those who are currently in one to have a partner who is currently a private pension scheme member. It is also of interest to note that a particularly large proportion of 'low' earners, both those who are and those who are not currently members of a private pension scheme, have a partner who is currently a private pension scheme member. This is because many 'low' earners are women who are working part-time (i.e. the 'low' earnings are a result of lower hours rather than lower wages) and many of these are living with a man who is on higher earnings and who is a member of a private pension scheme.

The penultimate row of Table 5.2 shows the median level of savings and investments of each category of individual (and, where relevant, their partner) in 1995. Median financial wealth among those who are not private pension scheme members in 2000 is $£ 400$, compared with $£ 2,028$ among those who are members. Given that those not in a private pension scheme typically have lower levels of liquid wealth, if they can afford to save then they might want to consider saving in a more liquid form rather than tying up their savings for 
retirement. ${ }^{14}$ Median financial wealth among those in the 'mid' earnings category who are not members of a private pension scheme in 2000 is just $£ 300$, compared with $£ 1,400$ among those 'mid' earners who do belong to one. This suggests that they may be a much more appropriate target group for Individual Savings Accounts than for stakeholder pensions.

\section{Saving}

Saving in financial assets other than pensions is potentially an important element in financial provision for retirement, and as such needs to be factored in to any understanding of the adequacy of retirement saving. The simple classroom 'consumption smoothing' paradigm used by economists suggests that individuals should borrow when their income is relatively low and expected to rise and should save, in order to finance consumption in the future, when they expect their income to fall. ${ }^{15}$ With income typically highest in middle age, this means individuals should borrow when young, accumulate assets through middle age and then decumulate these assets during retirement.

One consequence of this is that even within a distribution of 'equals', one might expect some degree of inequality in saving, whether measured in levels or as a proportion of income, and consequently even higher inequality in stocks of wealth, which reflect past decisions about saving and borrowing. Some of these differences will simply be due to age. But the timing of income receipts will also matter - two identical households with the same lifetime incomes but differing time paths for receiving this income will have the same consumption behaviour but different saving patterns. As a result, there may well be groups of the population for whom zero or low saving, or zero or low stocks of accumulated wealth, is the appropriate economic response to their circumstances.

Coupled with underlying inequality in lifetime incomes, this leads to considerable inequality in the distribution of saving and wealth, which has a number of implications. Firstly (for the reasons explained in the previous paragraph), not all low saving, or wealth inequality, is necessarily a cause for policy concern. Second, aggregate statistics can be very misleading with regard to the majority of households, since such statistics are dominated by the saving

\footnotetext{
${ }^{14}$ The importance of building up this type of precautionary saving before saving for retirement is described in HM Treasury, Saving and Assets for All, London, 2001 (www.hmtreasury.gov.uk/mediastore/otherfiles/36.pdf).

${ }^{15}$ See, for example: M. Friedman, A Theory of the Consumption Function, Princeton University Press, Princeton, NJ, 1957; R. E. Hall, 'Stochastic implications of the permanent income hypothesis: theory and evidence', Journal of Political Economy, 1978, vol. 96, pp. 339-57; or J. Campbell, 'Does saving anticipate declining labor income? An alternative test of the permanent income hypothesis', Econometrica, 1987, vol. 55, pp. 1249-73.
} 
patterns and wealth holdings of the very richest households. ${ }^{16}$ Third, borrowing and saving should be analysed jointly since they are interrelated in the sense that each facilitates the smoothing of consumption (relative to needs) over the life cycle, which, within the context of the economic model of behaviour, is the household's ultimate objective. If individuals are forced to increase their saving (for example, through increased compulsory retirement saving), it is not necessarily the case that current consumption will be reduced - individuals might instead simply choose to borrow more.

Finally, it should be pointed out that data on saving and wealth holdings of the population that are adequate to inform policy in the UK do not exist. Unlike many countries, the UK does not collect an official survey of household wealth and debt that could be used to provide empirical evidence in this area, although there is discussion of such a survey being developed. The collection of data that would facilitate a more detailed analysis than what follows is clearly desirable, and should be regarded as a priority for informing policy on saving, borrowing and wealth holding. In the following analysis, we use the Family Resources Survey (FRS), which is designed to measure individual and household incomes but has a small number of questions on asset ownership and one broad question on wealth levels, to provide a broad picture of the main issues. In addition to collecting very limited information on asset levels, the FRS does not collect information on outstanding debts, so we are unable to build this into the analysis.

Figure 6.1 shows the distribution of non-pension financial asset levels (defined in very broad bands) across all benefit units ${ }^{17}$ and within broad age groups. The graph shows that just over half of benefit units have less than $£ 1,500$ of financial assets, and that this proportion is over $70 \%$ when considering just those under age 35 .

\footnotetext{
${ }^{16}$ A further problem with the aggregate saving rate, in particular, as a measure of saving behaviour, is in the treatment of passive saving (i.e. accumulation through unrealised capital gains). For a discussion of this issue in the US context, see W. Gale and J. Sabelhaus, 'Perspectives on the household savings rate', Brookings Papers on Economic Activity, 1999:1, pp. 181-214, or A. Lusardi, J. Skinner and S. Venti, 'Saving puzzles and saving policies in the United States', Oxford Review of Economic Policy, 2001, vol. 17, no. 1, pp. 95-116.

${ }^{17}$ Throughout this section, we work at the benefit unit level to reflect the fact that savings are most likely held jointly by spouses or partners. A benefit unit is defined as a single adult or a couple (whether married or not) with dependent children. Hence, a non-dependent child living with their parents would be classified as a separate unit for the purposes of this analysis. Operating at the individual level would fail to account for joint asset holdings, which might be considered particularly inappropriate for middle-aged groups, particularly women, and in any case would place strong assumptions relating to the interpretation of the available data. Operating at the household level would fail to capture young adults without savings, pensions or housing if they lived in a household with middle-aged members owning such assets.
} 
Figure 6.1. Distribution of financial asset wealth, by broad age band

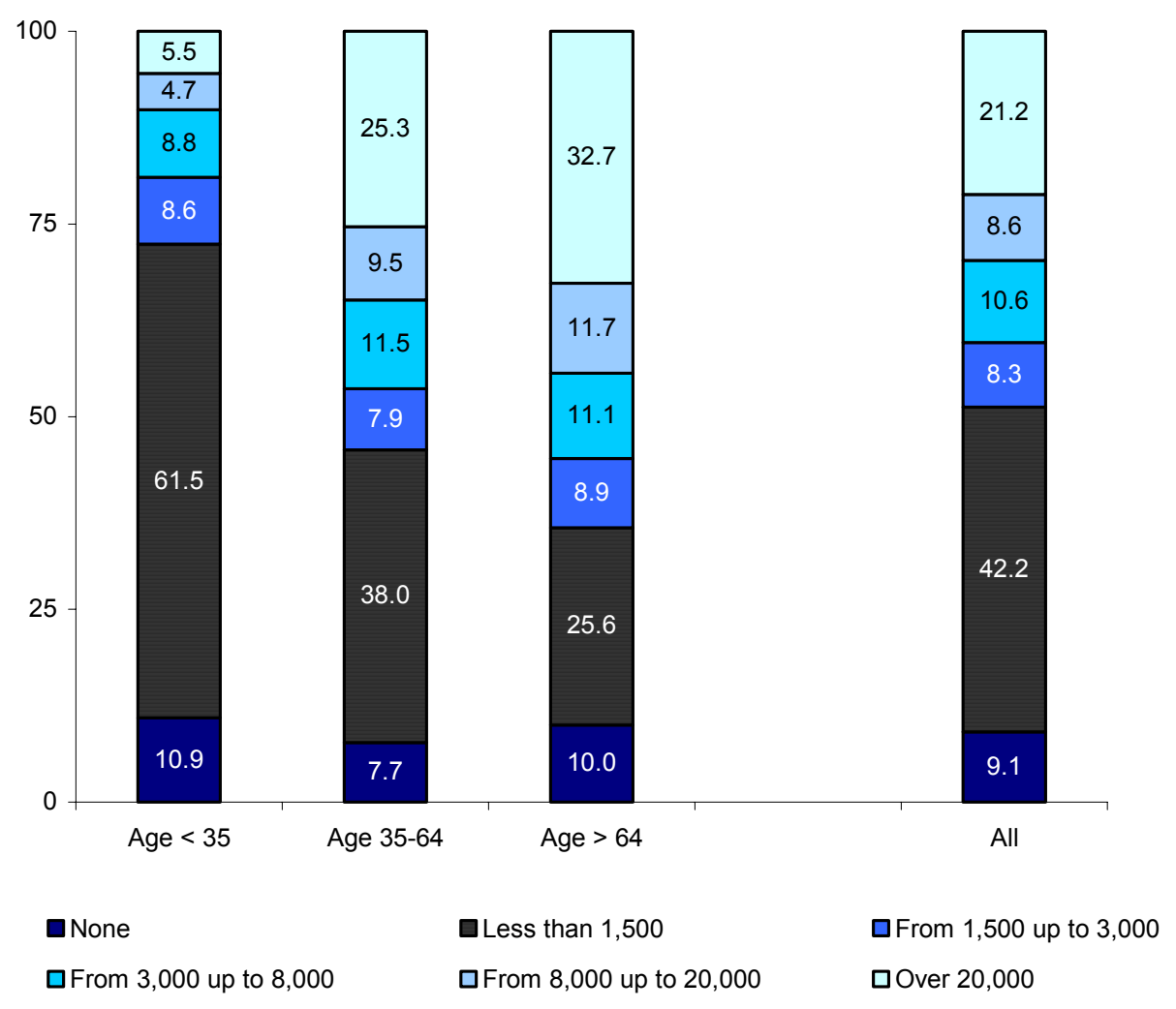

Note: Age refers to the age of the male when a benefit unit contains a couple.

Source: Family Resources Survey 2000-01; authors' calculations.

Table 6.1 shows that around one-quarter of benefit units aged under 65 have no private pension, no housing wealth and assets of less than $£ 1,500 .{ }^{18}$ Further calculations from the FRS data, however, reveal that almost three-quarters $(73 \%)$ of this group are either under age 25 or in the poorest quarter of the income distribution for their age. Given that the analysis in Section 4 showed that well over a quarter of families currently end up on means-tested benefits, and that the incentives for such a group to save are reduced (both because state benefits will replace a higher fraction of their pre-retirement income and because the marginal withdrawal rates they face on a pound of saving will be higher), it may well be the case that this situation is 'optimal' for such households, given the current policy regime. ${ }^{19}$ Certainly, it is difficult to make

\footnotetext{
${ }^{18}$ Age refers to the age of the male when a benefit unit contains a couple.

${ }^{19}$ For further discussion of the impact of the tax and benefit system and incentives to save for retirement, see T. Clark and C. Emmerson, The Tax and Benefit System and the Decision to Invest in a Stakeholder Pension, IFS Briefing Note no. 28, 2002 (www.ifs.org.uk/public/bn28.pdf).
} 
the case that these households are irrationally undersaving for their retirement, particularly when one considers that an extra pound of saving has to be funded by either an extra pound of borrowing or a pound less of consumption - neither of which would necessarily be appropriate for such a group.

Table 6.1. Broad asset ownership rates for benefit units with the head aged under 65

\begin{tabular}{ccc|c}
\hline $\begin{array}{c}\text { Savings over } \\
£ 1,500\end{array}$ & $\begin{array}{c}\text { Private } \\
\text { pension }\end{array}$ & $\begin{array}{c}\text { House } \\
\text { owner }\end{array}$ & \% of benefit units \\
\hline No & No & No & 25.69 \\
No & No & Yes & 7.65 \\
No & Yes & No & 6.46 \\
No & Yes & Yes & 12.74 \\
Yes & No & No & 4.42 \\
Yes & No & Yes & 8.45 \\
Yes & Yes & No & 5.89 \\
Yes & Yes & Yes & 28.69 \\
& & & 100.00 \\
\hline
\end{tabular}

Source: Family Resources Survey, 2000-01; authors' calculations.

Figures 6.2 and 6.3 investigate this point further by plotting the proportion of various groups of the population (defined by age and relative income) who have low levels of financial assets and, in Figure 6.3, do not have either housing wealth or pension wealth. The graphs show that there is a significant fraction of benefit units in all age groups that have low levels of financial assets. This fraction is still relatively high in all but the richest quarter of the income distribution within each age group. Once those with housing and pensions have been excluded, in Figure 6.3, the picture is changed. In particular, the proportion of middle-aged and middle-income families who have low savings and no housing or pension wealth is markedly lower than the overall proportion of them who have low levels of financial assets. The resulting numbers are consistent with the broad economic framework for saving decisions - the groups of the population with the least assets are the youngest and the poorest groups.

Although there are some older families who have low or zero savings and no housing and pensions wealth, it should be pointed out that the majority of these households (particularly those in the 55-64 age group) contain no employed adults and, as such, are presumably maintaining very low levels of income and therefore consumption. For this group, incomes will not vary as they move into retirement, and hence saving to facilitate further consumption smoothing would probably be unnecessary and ill advised for them. In addition, consumption may be very low for such households, and so reducing consumption levels further may be difficult. 
Figure 6.2. Proportion with less than $£ 1,500$ assets, by age band and quartile of income

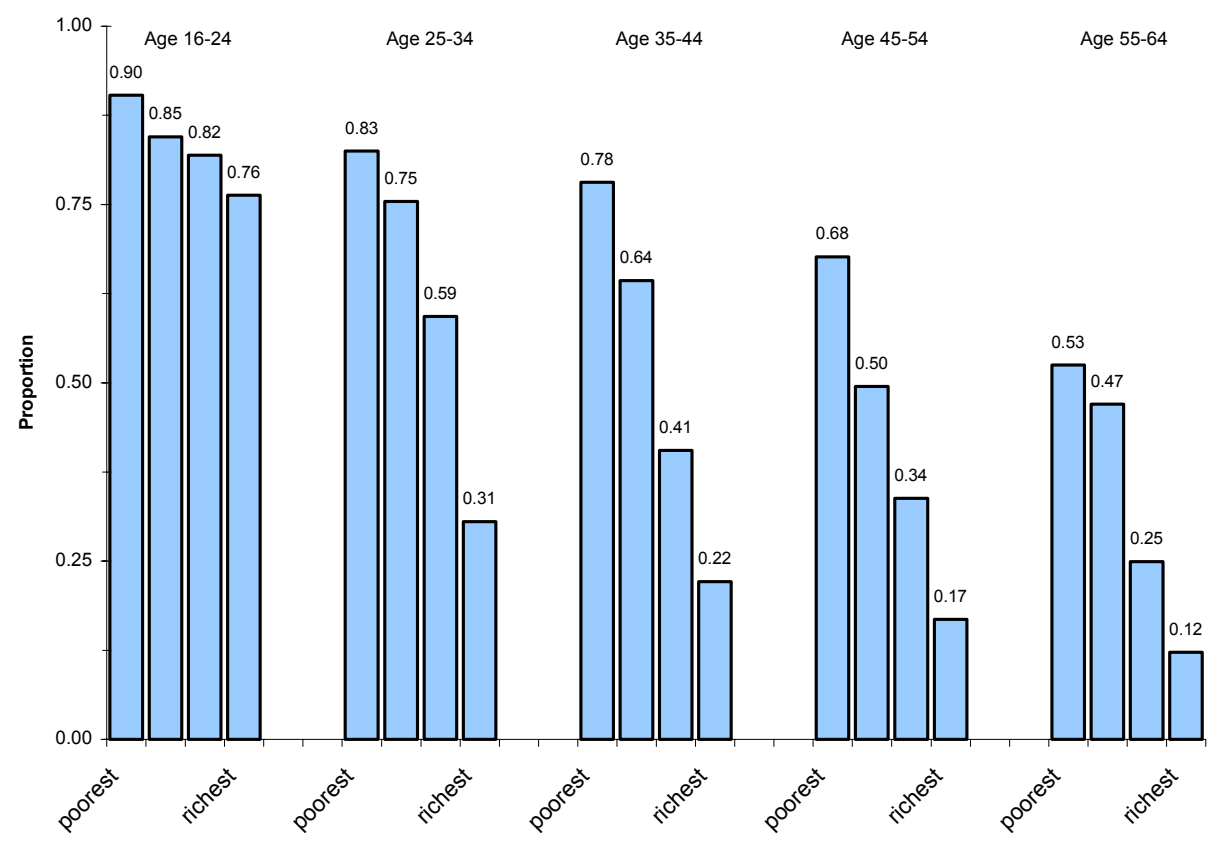

Source: Family Resources Survey, 2000-01; authors' calculations.

Figure 6.3. Proportion with less than $£ 1,500$ assets, no housing wealth and no private pension, by age band and quartile of income

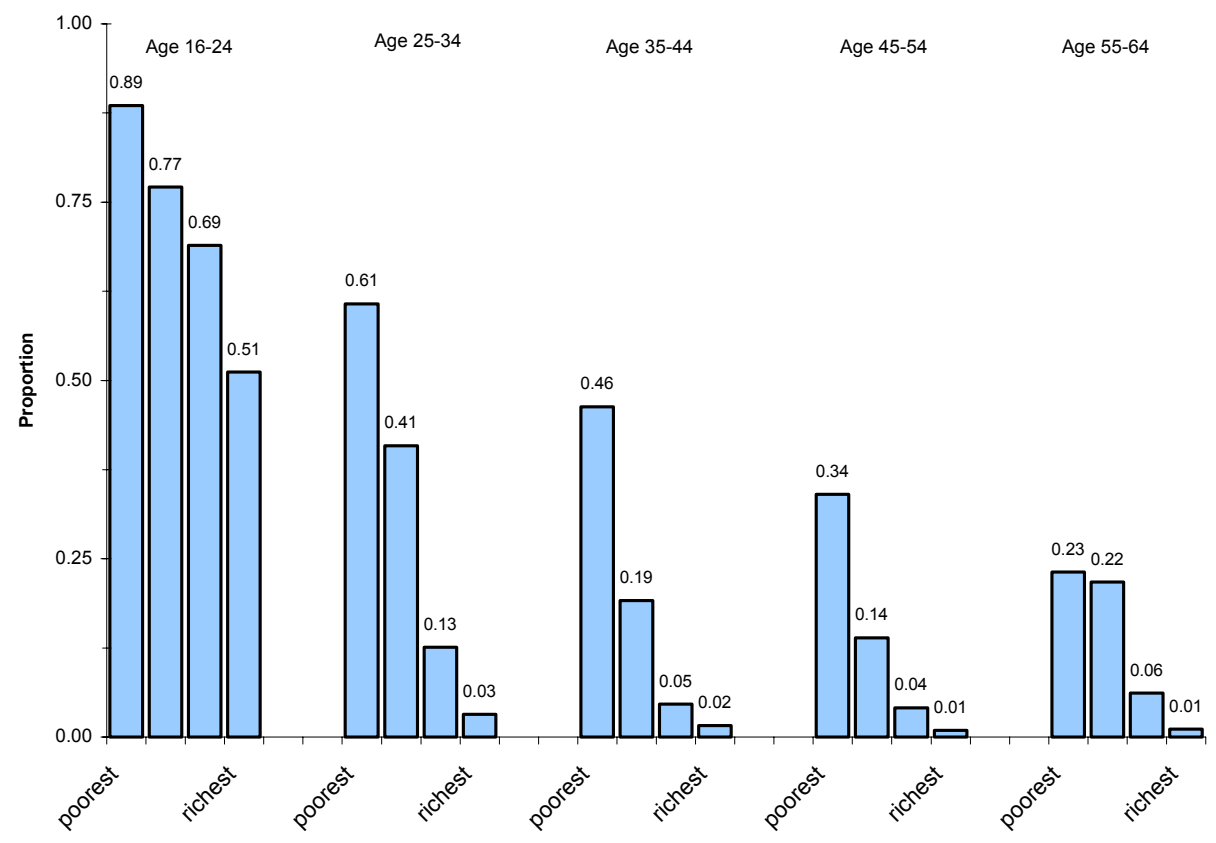

Source: Family Resources Survey, 2000-01; authors' calculations. 
A recent report by Oliver, Wyman \& Company ${ }^{20}$ attempts to calculate what individuals should be saving for their retirement. This amount is then compared with the amounts that individuals are actually currently saving. Across those who are believed to be saving too little, the total 'savings gap' is calculated to be some $£ 27$ billion (around $2.6 \%$ of national income). However, there are a number of difficulties with this type of analysis. The most obvious one is that individuals might have specific good reasons that are not revealed in quantitative surveys for why they are choosing to save less (or more) than the amount suggested by sophisticated economic models. One reason is that individuals' saving behaviour is forward-looking, and those who are not currently saving very much might expect their circumstances to change in the future. Low-income and younger individuals are particularly likely to be in this situation. Furthermore, many low-income individuals might sensibly decide that they should not currently be saving at all for retirement. ${ }^{21}$ Those who are currently on a low income will be either temporarily or permanently in that situation. Those who consider themselves to be temporarily on a low income might well decide to run down any financial assets (or to borrow) until their income rises again. Those who consider themselves to be permanently poor might expect to retire onto means-tested benefits (as shown in Section 4). The living standards provided by these benefits might not compare unfavourably with those experienced in their working lives. In addition, the withdrawal rates arising from means-tested benefits might lead a low-income individual to decide that the sacrifices involved in terms of current consumption are simply too great to justify the increase in retirement income that saving would generate. Of the estimated $£ 27$ billion 'savings gap', one-quarter is from individuals who are either aged under 25 or have a household income of less than $£ 9,500$. These groups might have particularly good reasons to decide not to save at the moment for their retirement.

One final issue with regard to saving and asset holding relates to the complexity of the savings environment, which has been a topic of particular concern in the policy debate. Whilst it is undoubtedly true that the UK financial environment is complex, the figures in this section suggest that such complexity may not necessarily be an issue for many households at their current margin. Neither savings accounts at the bank or building society nor Individual Savings Accounts are particularly complex products. Given the facts that these accounts (being typically characterised by quick access and safe rates of return) are the most appropriate vehicle for saving for households with lower income or asset levels and that the figures here have shown that such

\footnotetext{
${ }^{20}$ Oliver, Wyman \& Company, The Future Regulation of UK Savings and Investment, London, 2001. The executive summary is available at www.abi.org.uk/oliverwymanreport.pdf.

${ }^{21}$ In addition, the new state second pension is relatively much more generous to those who earn below $£ 9,500$ or who are caring for a dependent child aged under 5 than its predecessor, SERPS.
} 
households make up the majority of the population, complexity in (nonpension) financial assets is unlikely to be the reason behind the low saving for these groups. At the aggregate level, however, reducing complexity may have more of an effect, since aggregate saving and portfolios are driven so heavily by the saving and savings of the richest individuals and households.

\section{International issues}

How is the UK faring relative to other members of the European Union? What are the differences in pension arrangements across countries? What are the implications for public pension expenditure, and its growth over the next 40 years? And what are the differences in life expectancy and retirement patterns across countries? ${ }^{22}$

\section{International differences in retirement}

'Old-age dependency' is a demographic phenomenon; it does not describe whether or not people are economically inactive. In fact, most countries have seen a reduction in the age at which people typically retire, so that many people stop working before the age at which they can first receive a state pension typically 65 . The 'pension crisis' has arisen because people are living longer at the same time as they are retiring earlier. Simple arithmetic suggests that one means of alleviating the 'pension crisis' is for people to work into later life, so paying greater taxes into the public system and at the same time postponing the point at which they first draw a public pension. However, it is not easy to find policies that are effective in encouraging workers to delay retirement, particularly if there is a widespread perception among older workers that society prefers to see them replaced by younger workers with new skills and better training. It may be that uncertainty concerning the sustainability of public pension programmes, coupled with greater perceived risk attached to private pensions, will be the mechanisms that induce people to work longer in the next few years.

Table 7.1 shows how the 'average age of retirement' in 1995 varied across European countries - typically this age lies below 60-65, which is the age of first receipt of social security benefits. People can retire earlier either because they have a private pension (in those countries where such programmes exist) or because there are public programmes that permit early retirement on grounds of ill health and disability, or where long-term unemployment can be translated into early retirement. The 'routes' into early retirement differ across countries.

\footnotetext{
${ }^{22}$ Cross-country comparisons can be found on the OECD 'ageing society' website: http://www.oecd.org/EN/about/0,EN-about-26-nodirectorate-no-no-no-26,00.html.
} 
Table 7.1. International differences in retirement age

\begin{tabular}{l|c|cc}
\hline & $\begin{array}{c}\text { Life expectancy } \\
\text { at birth }\end{array}$ & $\begin{array}{c}\text { Average actual retirement age, 1995 } \\
\text { Men }\end{array}$ \\
\hline Portugal & 76.2 & 63.6 & Women \\
Denmark & 76.6 & 62.7 & 59.8 \\
Ireland & 77.0 & 63.4 & 60.1 \\
USA & 77.1 & 63.6 & 61.6 \\
New Zealand & 77.8 & 62.0 & 58.6 \\
Luxembourg & 77.9 & 58.4 & 55.4 \\
Finland & 78.0 & 59.0 & 58.9 \\
Germany & 78.2 & 60.5 & 58.4 \\
UK & $\mathbf{7 8 . 2}$ & $\mathbf{6 2 . 7}$ & $\mathbf{5 9 . 7}$ \\
Netherlands & 78.3 & 58.8 & 55.3 \\
Austria & 78.5 & 58.6 & 56.5 \\
Greece & 78.5 & 62.3 & 60.3 \\
Italy & 78.7 & 60.6 & 57.2 \\
Belgium & 78.8 & 57.6 & 54.1 \\
Spain & 78.8 & 61.4 & 58.9 \\
France & 79.0 & 59.2 & 58.3 \\
Canada & 79.4 & 62.3 & 58.8 \\
Australia & 79.8 & 61.8 & 57.2 \\
Sweden & 80.1 & 63.3 & 62.1 \\
Japan & 80.7 & 66.5 & 63.7 \\
\hline
\end{tabular}

Source: OECD, 1998 (ageing working paper 1.4).

Note that 'life expectancy at birth' is averaged across the sexes and is not, strictly speaking, the appropriate measure of length of retirement. We really need to know 'conditional life expectancy at age of retirement', which may be 2-3 years longer than life expectancy at birth, given infant mortality (see Figure 2.2 for life expectancies for men and women at age 65 rather than at birth in the UK, the USA, France and Japan).

Looking at Table 7.1, we can take as a rule of thumb that the average person can expect to be retired for 20 years. In a stable population where individuals worked for 40 years and retired for 20 years, there would be two workers to each retired person. Simple arithmetic implies that, for example, if retirement income is entirely financed through taxes on the working population, then to deliver an average pension equal to $50 \%$ of contemporary average earnings would require an average tax rate on earned income of $25 \%$. If the same example were calculated for a case where the population is ageing (as is true for many countries), then the necessary tax rate on labour would be increasing. 
It is also worth noting that trends over time in labour force participation differ significantly across countries. Women may typically retire somewhat earlier than men, but there are significant differences across countries in what fraction of women work and in how these fractions have changed over time. These are illustrated for some 'representative' countries in Figure 7.1.

Figure 7.1. ILO activity rates for adults aged 55-64
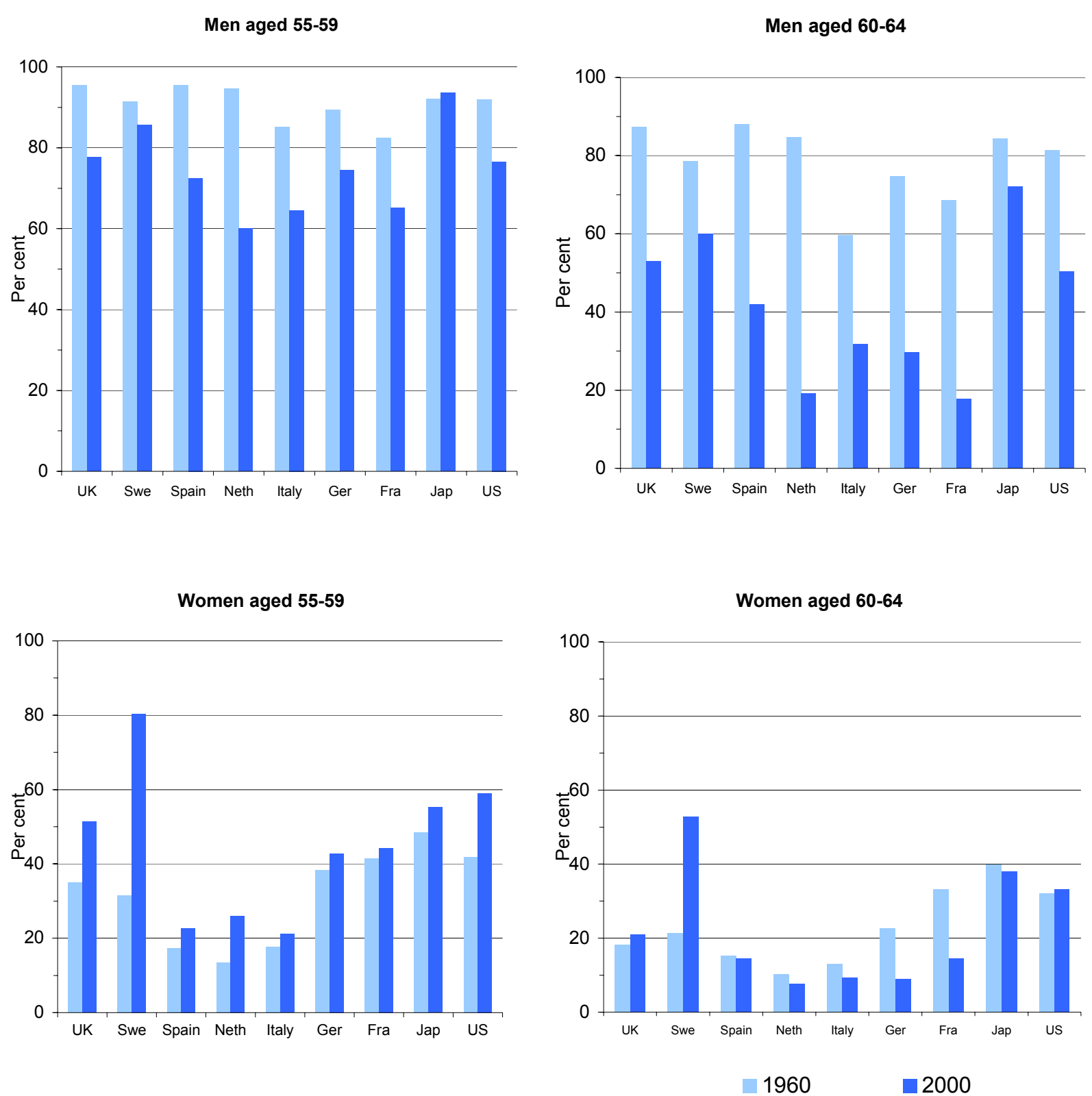

Note: The data in these graphs are derived from International Labour Organisation internationally comparable measures, and will differ slightly from the UK figures used earlier. Source: World Bank, 2001, www.worldbank.org/pensions/statistics. 
The panels making up Figure 7.1 show that almost all countries have seen comparable falls in participation in the labour force by men aged 55-59 and 60-64, although these have been much sharper in, say, France and the Netherlands than in Sweden and the UK. The big differences are among women, where the countries divide into three categories: those that have never had high participation by women (such as Italy and Spain), those that have seen declining participation by women aged 60-64 (such as France and Germany) and those that have seen increasing participation by women (such as Sweden and the UK). ${ }^{23}$

\section{Pension arrangements}

Every country has its own, specific, arrangements in providing pensions to the elderly. However, there are two basic types of pension provision, commonly called the Beveridge system and the Bismarckian system. ${ }^{24}$

The Beveridge system, of which the UK is obviously a prime example, has two tiers of provision. The first tier is publicly provided (tax-financed); the state provides a 'floor' of public provision, which is generally universal or disproportionately targeted on the poorest (such as the basic state retirement pension and, more specifically, the minimum income guarantee in the UK). The second tier or 'pillar' may include some public provision or state subsidy, but is largely provided by private, funded, pensions.

In a Beveridge programme, public provision tends to be redistributive and relatively low-cost, although there are various hidden subsidies and tax reliefs that support the private provision of the second tier. Other than the UK, European countries that have extensive second-tier private provision include Ireland, the Netherlands and Switzerland. Outside Europe, the USA, New Zealand and Australia are other countries with extensive private provision. The continent that has gone furthest down the road in 'privatising' social security is Latin America, following the path-breaking and controversial reform in Chile in 1981-82.

The Bismarckian system of pension provision is more common in continental Europe. Here, the state takes primary responsibility for earnings replacement in retirement. So benefits are related to lifetime earnings by some formula, which varies from country to country. For example, in the French and German schemes, individuals accumulate 'points' towards their final pension, which are revalued from time to time by the state. In other countries, pensions are

\footnotetext{
${ }^{23}$ For further discussion of differences in retirement behaviour across countries, see J. Gruber and D. Wise (eds), Social Security and Retirement around the World, University of Chicago Press, Chicago, 1999.

${ }^{24}$ See R. Disney and P. Johnson (eds), Pension Systems and Retirement Incomes across OECD Countries, Edward Elgar, Cheltenham, 2001.
} 
disproportionately related to earnings towards the end of the working life, as in final salary company schemes in the UK. In Sweden, entitlements are revalued in line with economic performance (GDP growth) in order to attempt to link pension arrangements to macroeconomic sustainability. These schemes will be less generous during periods of increasing average earnings but falling numbers in paid employment.

All Bismarckian schemes are tax-financed (unfunded) and intrinsically more expensive to the taxpayer than Beveridge-type schemes. Most countries using this system are therefore trying to reform their programmes to reduce their generosity and also to include a 'top-up' funded component, financed either privately or through a public 'trust fund'.

As mentioned above, the countries with extensive private pension provision similar to the UK's include the USA, Australia and New Zealand, and it is tempting to look to the experiences of these countries for evidence on pension reform and reform options. The US comparison is not particularly relevant for the UK policy debate because, whilst there is substantial private pension provision through Individual Retirement Accounts and 401(k) employer pension plans, this provision is additional to, instead of a substitute for, the state 'second-tier' pension (which is called Social Security in US parlance). This is not the case in the UK, where the majority of employees have chosen to contract out of the earnings-related element of the state scheme into a private pension.

More interesting lessons can perhaps be learned from Australia and New Zealand. The Australian retirement income system has two main components a flat-rate means-tested age pension funded from general tax revenue, and private occupational superannuation. ${ }^{25}$ It differs from the UK system in three respects: public provision is wholly means-tested (there is no 'social insurance' component), it is based wholly on a residency requirement, and private pension saving is mandatory. The means-tested pension is somewhat more generous than the minimum income guarantee in the UK and is available at 65 for men and 60 for women (these ages are being equalised in stages to 65).

In fact, fewer than $20 \%$ of people of pensionable age are excluded from the means-tested pension in Australia. This is because people can avoid the income test by fully retiring and the asset test by outright purchase of certain assets, notably their home, for which the asset test is less stringent. It is the field of private provision where Australia has seen more controversy. In the 1980s, roughly half of workers were covered by occupational pension schemes. Under pressure from trade unions to widen coverage and also to increase wages, employers and the government agreed in 1992 to introduce a compulsory

\footnotetext{
${ }^{25}$ A. King, H. Bækgaard and A. Harding, 'Pension provision in Australia', in R. Disney and P. Johnson (eds), Pension Systems and Retirement Incomes across OECD Countries, Edward Elgar, Cheltenham, 2001.
} 
contribution from employers into individual retirement accounts, starting at 3\% of income and rising to $9 \%$ in stages. Typically, the tax incentives (which are, in other respects, fiendishly complicated in Australia) encourage employees to make additional contributions to their private pension account.

This combination of an income-tested flat-rate state pension coupled with (effectively) mandatory employer and individual contributions to private retirement saving accounts in Australia has undoubtedly influenced the debate within the Labor administration as to how to reform pensions in the UK. However, there are certainly complexities and disincentives arising from the combination of means testing of the basic state pension and taxation of the private plans when individuals draw their pensions that remain unresolved problems with the Australian 'model'.

New Zealand shares some features with Australia but more with the UK, particularly its continued tinkering and reform processes that have led to several new policies over a very short period. The basic New Zealand provision is a universal flat-rate pension available at 65 based on a simple residency requirement and set at a somewhat more generous level than in the UK. ${ }^{26}$ The main controversy that has arisen in New Zealand is whether there should be tax-subsidised opportunities for private retirement saving over and above the state-provided minimum. At several stages, imitating Australia, compulsory private saving has been proposed or even introduced, but at other stages, payments from the private scheme have been surcharged or tax reliefs reduced. So, unlike Australia, where public pensions are income-tested and private pensions are free of asset tests, the reverse was the case in New Zealand through much of the 1990s. Although explicit surcharging of payments from private pensions ended in 1998, the government's decision to end any special tax reliefs for occupational pensions from 1990 has reduced coverage by employer-run schemes and given a boost to some non-pension forms of saving (e.g. owner occupation). In recent years, there have been a plethora of official reports and committees to discuss, in particular, the form and extent of private pension saving arrangements, but agreement seems far away.

\section{European pension and public finance issues}

Current state expenditures on pension systems vary widely across the EU. Table 7.2 depicts official European Commission figures on the costs of financing public pension requirements across EU Member States in 2000. The costs are taken from age 55 as countries differ in their retirement ages (as was shown in Table 7.1) and also various types of early retirement provision, including provisions related to 'unemployability' and disability. In general, although there are country-specific differences, the 'Bismarckian' regimes of

\footnotetext{
${ }^{26}$ S. St John, 'Pension provision in New Zealand', in R. Disney and P. Johnson (eds), Pension Systems and Retirement Incomes across OECD Countries, Edward Elgar, Cheltenham, 2001.
} 
continental Europe are much more expensive than the 'Beveridge' schemes such as that of the UK. Other differences arise from whether countries have embarked on significant reforms to cut back on entitlements in recent years.

Table 7.2. Public pension spending on people aged $55+$ as a $\%$ of national income

\begin{tabular}{l|c}
\hline & 2000 \\
\hline Austria & 14.5 \\
Italy & 13.8 \\
Greece & 12.6 \\
France & 12.1 \\
Germany & 11.8 \\
Finland & 11.3 \\
Denmark & 10.5 \\
Belgium & 10.0 \\
Portugal & 9.8 \\
Spain & 9.4 \\
Sweden & 9.0 \\
Netherlands & 7.9 \\
Luxembourg & 7.4 \\
UK & $\mathbf{5 . 5}$ \\
Ireland & 4.6 \\
& \\
EU & 10.4 \\
\hline
\end{tabular}

Source: European Commission Economic Policy Committee, Budgetary Challenges Posed by Aging Populations, Brussels, 2001 (http://europa.eu.int/comm/economy finance/epc).

The European Commission also produces 'standardised' projections up to 2040 based on agreed assumptions about demographic trends, participation rates and so on. Statistics reported by individual countries may differ from these figures. ${ }^{27}$ Whether or not a pension system is sustainable is likely to depend, in part, on how the future costs of the system compare with the current costs. Differences between current and projected costs arise partly from the differential maturity of programmes - that is, whether programmes have been in operation long enough for a full 'cohort' of retired people to have been in the programme from entering the labour force until retirement. Programmes that were developed relatively later (such as Spain's) will still see an increase in claimant numbers arising from maturation as well as demographic ageing. Moreover, countries differ radically in their rates of fertility and labour force growth.

\footnotetext{
${ }^{27}$ For further details, see European Commission Economic Policy Committee, Budgetary Challenges Posed by Aging Populations, Brussels, 2001

(http://europa.eu.int/comm/economy finance/epc).
} 
Figure 7.2. Forecast change in public pension spending as a \% of national income, 20002040 (percentage points)

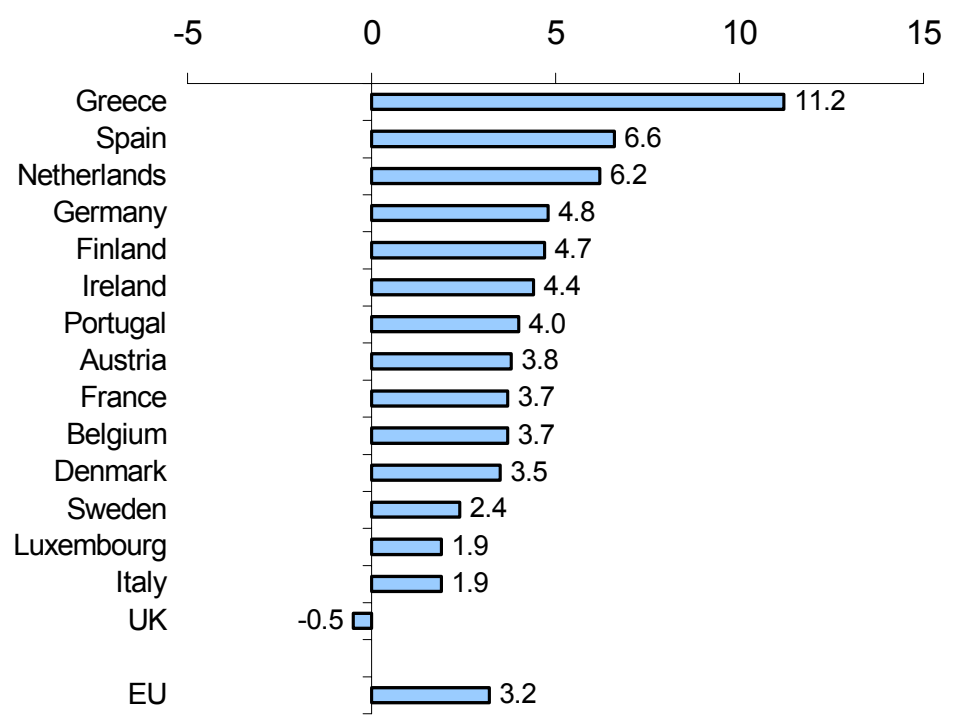

Figure 7.3. Old-age dependency ratio (\%)

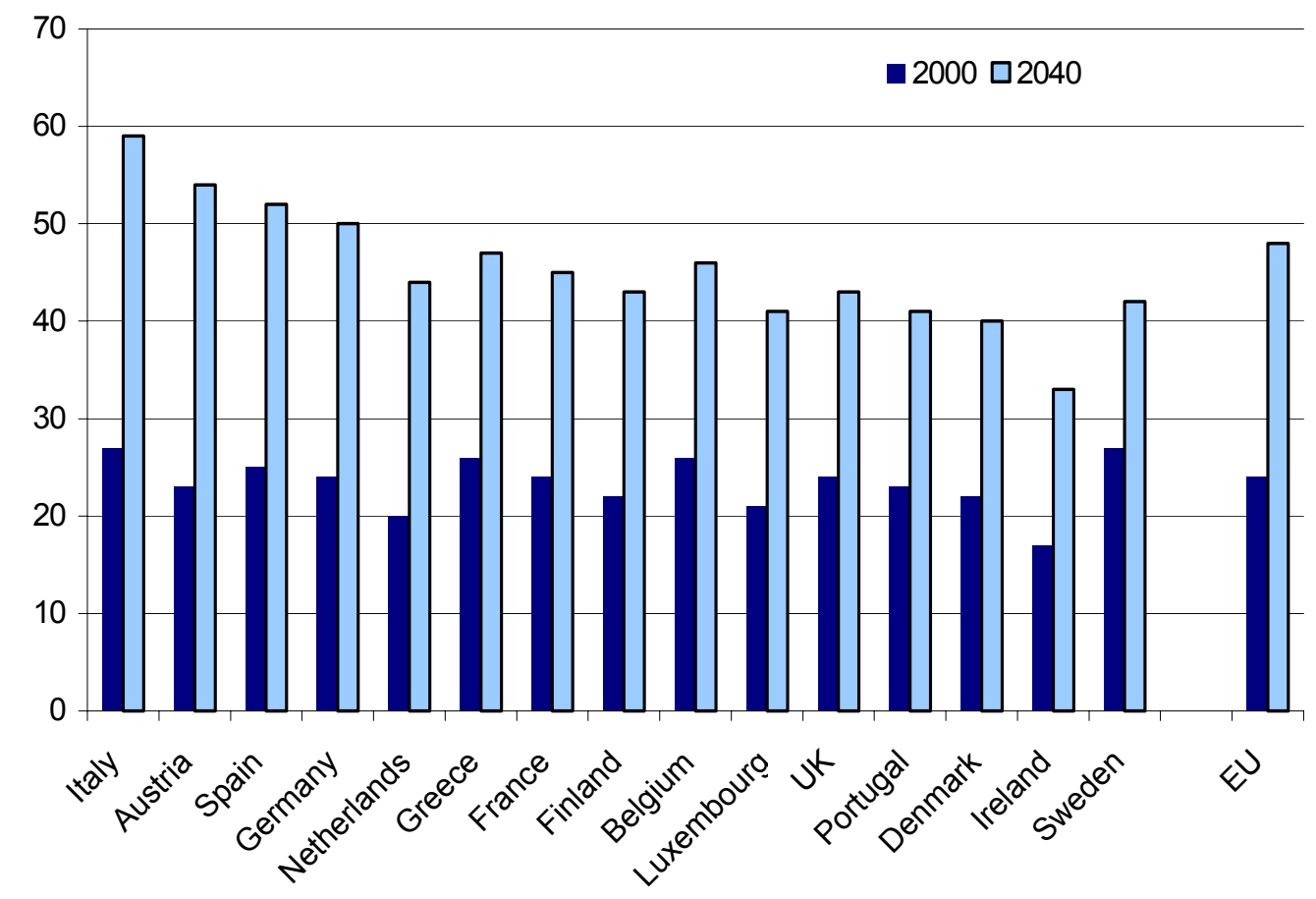

Source: EUROSTAT.

All these differences combine to produce disparate changes in public pension costs over the next 40 years, as illustrated in Figure 7.2. This shows that the $\mathrm{UK}$ is the only country where costs, as a percentage of national income, are 
projected to fall. Bear in mind, however, that these figures ignore the costs of private provision, and also of tax reliefs and any 'safety net' provisions underwritten by the government for the private sector. Some countries (such as Ireland) see sharp increases from a low base (this is largely a demographic change). Other countries (such as Italy) already have a high cost but seem to have contained future increases. Other projections simply seem unsustainable (Greece).

Figure 7.3 illustrates the level of the old-age dependency ratio for each EU country in 2000 and its projected level in 2040, calculated by EUROSTAT. The old-age dependency ratio is defined as the population aged 65 or over divided by the population aged 15-64. It abstracts from differences in economic activity rates across countries - some countries may have many retired people below 65, for example. There are also large differences in employment rates across countries, especially of married women and of young people.

Overall, the EU old-age dependency rate doubles between 2000 and 2040, from $24 \%$ to $48 \%$, with the biggest change being in Italy (increasing by 32 percentage points) and the smallest in Sweden (increasing by 15 percentage points). The UK has a slightly below-average increase in demographic dependency - typically, the Mediterranean countries exhibit a faster increase in dependency than more northern countries.

This all suggests that many EU members face significant increases in their public pension costs. Under the Maastricht criteria, there are ceilings on both public debt and the public sector deficit as a share of national income (set at $60 \%$ and 3\% respectively; note that this debt measure does include pension liabilities). This rules out debt and inflation financing as means of paying for future pension costs. Consequently, Member States will either have to reduce the generosity of their pension arrangements or have to raise taxes.

Member States are free to pursue their own social security policies (i.e. there has been no attempt to 'harmonise' disparate pension programmes). The Commission or legal authorities cannot intervene directly to 'force' countries to change their pension programmes. However, the Broad Economic Guidelines and the Growth and Stability Pact do permit Member States to examine the sustainability of the public finances of individual countries and to provide for benchmarking of individual country employment strategies. There is now a more systematic attempt to bring public spending on pensions and health into this agenda. ${ }^{28}$

\footnotetext{
${ }^{28}$ For further discussion of these issues, see T. Boeri, A. Börsch-Supan, A. Brugiavini, R. Disney, A. Kapteyn and F. Parrachi (eds), Pensions: More Information, Less Ideology. Assessing the Long-Term Sustainability of European Pension Systems, Kluwer Academic Publishers, Boston, 2001, and also R. Disney, 'Crises in public pension programmes in OECD: what are the reform options?', Economic Journal (Features), February 2000, pp. F1-F23.
} 
Table 7.3. Potential reforms to reduce future state pension expenditures

\begin{tabular}{|c|c|}
\hline Broad strategy & Example policies \\
\hline \multirow[t]{2}{*}{ 1. Reducing the generosity of schemes } & $\begin{array}{l}\text { Indexing pension benefits to prices rather } \\
\text { than earnings }\end{array}$ \\
\hline & $\begin{array}{l}\text { Calculating pensions on average lifetime } \\
\text { earnings rather than final earnings }\end{array}$ \\
\hline \multirow[t]{2}{*}{ 2. Attempting to induce people to retire later } & Raising the state retirement age \\
\hline & $\begin{array}{l}\text { Tightening up eligibility conditions for } \\
\text { early retirement }\end{array}$ \\
\hline \multirow[t]{2}{*}{ 3. Introducing some pre-funding of pensions } & 'Top-up' private contributory scheme \\
\hline & $\begin{array}{l}\text { Additional payroll taxes so that a 'surplus' } \\
\text { can be accumulated to offset the tax rise } \\
\text { required in future }\end{array}$ \\
\hline
\end{tabular}

In any event, most EU Member States are, albeit with varying degrees of enthusiasm, attempting to reform their public pension programmes. There are three broad types of reform that have been used by countries, as described in Table 7.3.

Many of these reforms are recent and it is too early to evaluate all their longterm effects. For example, a succession of reforms to the public pension programme in Italy has stabilised spending on the programme, albeit at a very high level. The effects of these structural reforms on retirement behaviour are harder to interpret, however, although it seems likely that measures designed to reduce the attractiveness of early retirement (tighter conditions on disability, raising the 'normal' state pensionable age, extra tax incentives to retire later) will gradually increase the average age at which people retire in Europe.

The UK will not have to contribute directly towards the pension liabilities of the rest of Europe. Public programmes are not harmonised and each country has to finance its own programme. However, if countries find it increasingly hard to maintain their public finances in the face of increased demands from the pension programme, there may be pressure to relax the arrangements in the Growth and Stability Pact. For example, increased pension liabilities might lead to a relaxation of the debt and borrowing ceilings. If this pushed up interest rates in Euroland, then the UK consumer and producer would also be affected, and, given capital mobility, this would occur irrespective of whether the UK joins the Euro. On the other hand, the Commission and European Finance Ministers are well aware of these risks, and we can expect to see continued indirect pressure on some Member States to implement sustainable pension programmes rather than resort to deficit financing of existing arrangements. 


\section{Conclusions}

The facts that the state pension system is becoming relatively less generous for those not on means-tested benefits, that employers are shifting from defined benefit to defined contribution pension schemes and that life expectancies are increasing have all been put forward as reasons why the UK pension system is in crisis. Even if these phenomena are now happening at an increasing rate, it is important to note that none of them is actually new. The level of social assistance available to pensioners has typically been more generous than the basic state pension. Coverage of defined benefit schemes has been in decline since the mid-1980s. Continued increases in life expectancies are hardly a surprise. But the key issue remains a relevant one, and can be boiled down to the question 'How can we at least maintain post-retirement levels of income while the population continues to age?'. Being able to do this seems likely to necessitate either growing levels of retirement saving (either individually or collectively through employers or the state) or longer working lives, or a combination of both.

This might not be a problem for government policy. The current UK pension system allows individuals an extremely large amount of choice over how much, and in what form, to save privately for retirement. While there are a significant and growing number of retired people in receipt of means-tested benefits, many working-age individuals will want to save, and are saving, for their retirement. Coverage of private pensions across the earnings distribution does not look inappropriate, and the majority of middle earners already have some form of private pension. As we highlighted in Section 5, many of those middle earners who do not save in a private pension appear to have sensible reasons for choosing not to do so. Moreover, the data presented in Section 6 highlighted that those with less than $£ 1,500$ in financial assets who also have neither a private pension nor any housing equity tend to be either young or in the bottom half of the (age-specific) income distribution or both. This seems reasonable. Given the paucity of available data, it is currently extremely difficult to assert confidently that individuals are not saving enough. Better data on individuals' liquid financial assets, their housing wealth, their pension wealth and also their debts would be an extremely useful aid to policy-making in this area.

It is of interest to look at individuals' current levels of financial assets and calculate whether there is a 'gap' between the saving that they are currently doing and the amount that they would need to save to reach a target level of income. It should be noted, though, that evidence of a 'gap' does not necessarily answer the question as to what, if anything, the government should do. Saving behaviour and retirement plans will change in the light of changing circumstances, and individuals may automatically adjust their behaviour if the 'savings gap' has arisen as a result of events that were unforeseen when they made their original plans - for example, if the stock market or their pension over- or under-performed compared with their expectations, or if their labour 
market experiences differed from what they had initially expected. Furthermore, even if no 'savings gap' were identified, there might still be valid reasons for policy changes - for example, if the government wanted to redistribute different amounts towards different groups of pensioners.

It is also important not to take low incomes in retirement as evidence of inadequate retirement saving per se. Many households with low retirement incomes will have had low lifetime incomes, and retirement saving may not have been an appropriate activity for them. Means-tested benefits replace a large fraction of earned income when such households retire, and in this situation, particularly given consumption needs that are high relative to income, a reliance on government-provided retirement income may well be 'rational'. Therefore, if it is felt that individuals are not making appropriate saving decisions, then it is important to be clear about why these decisions are not appropriate. In the previous case, individuals are making sensible decisions based on their own circumstances, but there may be a feeling that, perhaps due to the increased reliance on means-tested benefits, these decisions are not optimal from society's point of view. This will depend on how much these individuals would have saved if means-tested benefits were less generous. Another possibility is that individuals are not making sensible saving decisions even from their own perspective. This could be due to the complexities of the UK pension and financial systems. More financial education may well have an important role to play in aiding better saving decisions.

Improving the information that individuals have at their disposal is hindered further by the fact that past experience has shown that the next 'radical' pension reform is never likely to be far away. There have been a large number of pension reforms over the last 20 or so years, many of which have had the effect of adding new complexities. New reforms that add new parts to the pension system have tended to try to avoid creating immediate losers and hence they typically leave a long transition to the 'reformed' system. This has the advantage of a more stable regime for those who are nearer to retirement but often creates a more complex pensions environment for younger individuals.

This Briefing Note has described various factors that must be considered before a view of appropriate pension policy can be formed. The alternative to working-age individuals consuming less today in order to consume more in their retirement is for them to work for longer. Given the reductions in employment rates among older men (shown in Section 3) and the phenomenal increase in the number of individuals claiming disability benefits (shown in Section 4) over the last 20 years, the government should certainly examine whether reforms could be made that improve work incentives. Final salary defined benefit schemes typically provide individuals nearing retirement with a strong incentive either to work full-time or to retire. The shift from these schemes, in conjunction with increasing numbers of individuals approaching retirement with personal pensions, will reduce the numbers faced with this distortion. This should lead to an increase in more flexible working patterns 
with more individuals choosing to withdraw gradually from the labour market by working part-time. While this might lead to individuals working for longer, it is also possible that individuals will choose to withdraw partially from the labour market at an earlier age than they would have done.

The other strategy that the government should consider is whether appropriate policies can be used to stimulate employment amongst older workers. On the one hand, Section 7 showed that, with the notable exception of Sweden, employment rates among older workers are actually relatively high in the UK compared with other European countries. On the other hand, however, the data also show that employment rates among older women are higher in the USA than in the UK, and that Japan has higher employment rates among both older men and older women. In addition, employment rates among men in the UK are also much lower than they have been previously. The evidence we have presented has shown that many of the older workers not in employment are on some form of disability benefit. In the short run, it may be hard to move such workers into employment, but in the medium term and beyond, reforms that reduce the flow onto such benefits would very likely increase participation rates among older men in particular.

As is clear from the above, many unanswered research questions will be key to outcomes in the future. These include: Can and will the labour market absorb more older workers? What are the consumption needs of older households? To what extent will individual behaviours (at either the saving or the retirement margin) adjust to meet the pressures of retirement income provision in an ageing population? The private and increasingly individual pension provision approach being taken in the UK adds an extra piece to the puzzle - information provision. Financial education and the simplicity and stability of the planning environment become key to individuals being able to implement their financial plans for retirement.

The government should certainly avoid the temptation to carry out yet more pension reform without carefully considering why that reform should take place. Many would welcome reform that achieved a simpler pension system. Often, this involves ideas aimed at reducing the number of retired people who are eligible for means-tested benefits. The choices here are difficult. Removing elements of the means-tested system such as the pension credit without carrying out any other reforms will lead to lower-income pensioners losing out. Increases in other benefits could be used to compensate these groups - for example, through large increases in either the basic state pension or the state second pension. However, this would require increases in tax. Another possibility is to reconsider the targeting of the current incentives to save in a private pension, through the contracted-out rebates and the tax-free lump sum. The Green Paper in the autumn is an ideal opportunity for the government to make a clear statement of its objectives. This would allow for debate to take place over whether those objectives are the right ones to have and what the most appropriate policy action is to achieve those objectives. 